\title{
Sedimentological and palaeohydrological characterization of Late Pleistocene and Holocene tufa mound palaeolakes using trenching methods in the Spanish Pyrenees
}

\author{
XAVIER M. PELLICER*, JUAN PABLO CORELLA†, FRANCISCO GUTIÉRREZ †, \\ CARLES ROQUÉ§, ROGELIO LINARESף, DOMINGO CARBONEL\$, MARIO ZARROCA \\ JESÚS GUERRERO\$ and XAVIER COMAS * * \\ ${ }^{*}$ Geological Survey of Ireland, Beggars Bush, Haddington Road, Dublin, Ireland (E-mail: xavier. \\ pellicer@gsi.ie) \\ $\uparrow$ Institute of Physical Chemistry Rocasolano, Serrano 119, 28003 Madrid, Spain \\ $\$$ Departamento de Ciencias de la Tierra, Universidad de Zaragoza, Zaragoza, Spain \\ $\S$ Àrea de Geodinàmica Externa i Geomorfologia, Universitat de Girona, Girona, Spain \\ IDepartment of Geology, Autonomous University of Barcelona, Bellaterra, Barcelona, Spain \\ **Department of Geosciences, Florida Atlantic University, Davie, FL, USA
}

Associate Editor - John Reijmer

\begin{abstract}
Lakes developed in the inner depressions of tufa mounds are rare geomorphic features and still poorly understood. Sedimentation in this unusual type of endorheic lake with a very restricted catchment area is highly sensitive to environmental and hydrological changes. The Isona tufa mound complex, north-eastern Iberian Peninsula, is associated with the discharge zone of a confined artesian aquifer and comprises 11 tufa mounds consisting of an annular rimstone enclosing a central depression filled with lake deposits. Data gathered from trenches excavated in four palaeolakes located within three different morphostratigraphic units permitted a precise analysis of the geometrical characteristics and stratigraphic relationships of the deposits and provided a sedimentation model for the Late Quaternary infilling of the spring-fed lakes. The work illustrates that trenches allow a precise characterization of the stratigraphic arrangements, lateral facies changes and deformation structures, which are not apparent in studies relying solely on borehole records, and facilitate sampling for dating and geochemical analyses. The five sedimentary facies described represent different evolutionary stages of the lakes, including: (i) carbonate-rich palustrine deposits probably related to periods with strong hydrological seasonality; (ii) massive highly bioturbated organic ooze; (iii) banded organic carbonate-rich facies associated with an increase in the regional effective moisture; (iv) finegrained quartz-rich aeolian/slope-wash sediments; and (v) colluvial facies deposited following the desiccation of the lakes located at higher altitudes. Geochemical and sedimentological analyses of the lacustrine sequences provided information on the palaeohydrological evolution of the Isona tufa mound complex and the palaeoenvironmental conditions of the area over the last 28 ka. Radiometric dating suggests that deposition occurred simultaneously at $c a 22 \mathrm{ka}$ in palaeolakes situated at different elevations. A drop in the piezometric level prompted by the opening of springs at lower altitudes probably caused the deactivation of the upper springs and the desiccation of the lakes. Arid conditions prevailed in the area during the Late Glacial and the early Holocene (28.0 to $8.5 \mathrm{ka} \mathrm{BP}$ ). More humid conditions
\end{abstract}


recorded from 8.5 to $4.2 \mathrm{ka}$ and again since $1.7 \mathrm{ka}$ are in accordance with palaeoenvironmental reconstructions available in the Western Mediterranean since the Last Glacial Maximum.

Keywords Basturs, lake sediments, palaeoclimate, palaeohydrology, trenching methods, tufa mounds.

\section{INTRODUCTION}

Tufas consist of continental highly porous carbonate deposits rich in plant remains associated with temperate waters (Pedley, 1990). Tufa mounds form by calcium carbonate accumulation around subaerial or subaqueous springs in which groundwater discharges under pressure through a well-defined vent (Hancock et al., 1999; Pentecost, 2005). These mounds typically form on relatively flat surfaces and may reach more than $100 \mathrm{~m}$ in height; their cross-profile may display a wide range of geometries, from steep-sided conical structures to broad mounds with gentle slopes. Tufa mounds generally comprise a central subcircular lake associated with the feeding vent, surrounded by an annular rimstone. The water of the elevated lake may overflow and cascade radially along the outer slope of the rimstone (Fig. 1). Spring waters with a high degree of supersaturation and significant hydraulic head favour rapid deposition just around the vent and the development of mounds with a high aspect ratio (i.e. height to width). Springs may become inactive and change their location when the mounds grow above the piezometric level. Tufa mounds formed under subaqueous conditions, typically displaying a columnar geometry, have been used to infer lake level oscillations (Benson, 2004; Rosen et al., 2004; Guo \& Chafetz, 2012; Renaut et al., 2013).

Most of the documented mounds formed in subaerial conditions correspond to thermogene travertine build-ups associated with geothermal systems (e.g. Altunel \& Hancock, 1993; Guidry \& Chafetz, 2003; Pola et al., 2014). These deposits record vent locations for mantle-derived $\mathrm{CO}_{2}$, which was conveyed by deeply sourced hydrothermal fluids (e.g. Priewisch et al., 2014; Claes et al., 2015; Toker et al., 2015). In contrast, the works on meteogene terrestrial tufa mounds are quite scarce. The most comprehensive investigations are those dealing with the tufa mounds of the Great Artesian Basin in Australia (Keppel et al., 2011, 2012) which are related to spring waters with very long residence times. Despite the scarcity of investigations on meteogene mounds, these depositional landforms are of special interest for several reasons: (i) they provide information on the characteristics, behaviour and geological evolution of aquifers. Relict mounds constitute evidence of palaeosprings and are useful tools for palaeohydrogeological reconstructions; and (ii) tufa mounds and associated lakes may constitute potential archives of climate and environmental variability, especially when the groundwater has a short residence time, like in the small and rapid-response hydrogeological system investigated in this study.

The Isona tufa mound complex (ITMC), located in the discharge zone of a confined artesian aquifer in the Spanish Pyrenees, includes 11 subcircular depressions associated with tufa mounds and related to former groundwater outlets (Linares, 1995). These peculiar crater-like features consist of a central depression filled with lake deposits and enclosed by an annular more resistant tufaceous rimstone (Fig. 1). The tufa complex developed in association with non-thermal artesian springs ( 14 to $19^{\circ} \mathrm{C}$; Linares et al., 2010a) of calcium-bicarbonate-rich waters, perched above the local drainages. The elevation of both the base level of erosion and the groundwater outlets has changed throughout the evolution of the system in relation to the episodic entrenchment of the drainage network, as recorded by stepped sequences of fluvial terraces and mantled pediments (Linares et al., 2010a; Roqué et al., 2013). Calcium carbonate precipitation around the artesian springs induced by $\mathrm{CO}_{2}$ degassing, aided by biogenic activity and local increase in turbulence (Ford \& Pedley, 1996; Keppel et al., 2012), resulted in the progressive upward growth of tufa mounds topped by annular rimstones enclosing quasi-circular lakes (Fig. 1).

Sedimentation in this type of lake, with a particularly small catchment area, is highly sensitive to environmental and hydrological changes. Tritium $\left({ }^{3} \mathrm{H}\right)$ concentration of groundwater sampled from springs, lakes and wells in the aquifer system suggest a residence time of less than 30 years (Linares et al., 2008). Moreover, the lag time between rainfall events in the recharge area 

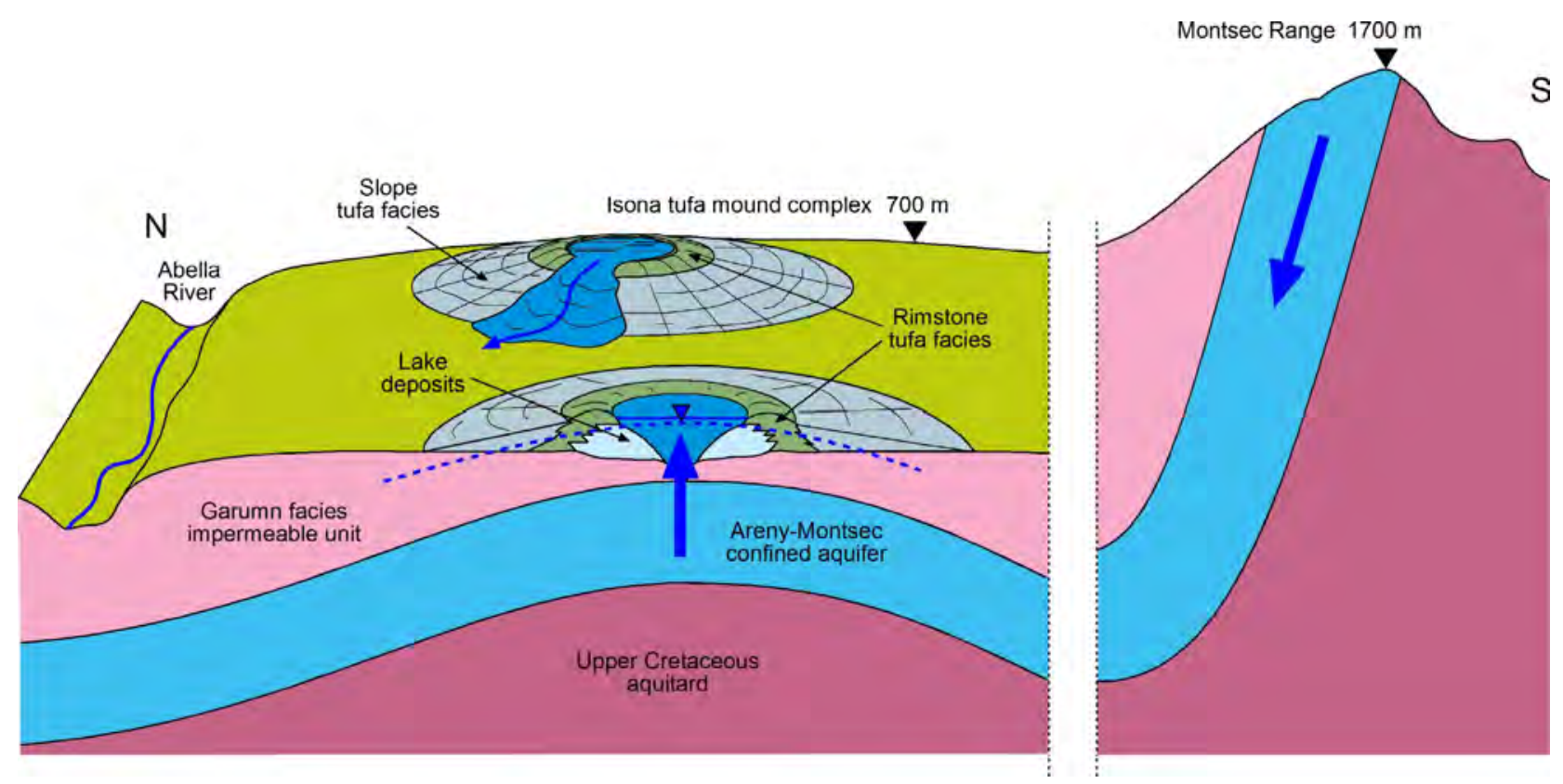

Fig. 1. Sketch illustrating the hydrogeological setting of the Isona tufa mound complex (ITMC) and the internal architecture and development of the tufa mounds. Tufa mounds grow through vertical accretion of annular rimstones by recurring overflow events at shifting locations. Lacustrine sediments accumulate in the elevated central depressions developed within the mounds.

and the corresponding response in the springs was estimated at around one month (Linares, 1995). Thus, detailed stratigraphic analyses of the palaeolake deposits in combination with geochronological and geochemical data should provide valuable palaeoenvironmental and palaeohydrogeological information.

Knowledge of the Holocene palaeoclimatic evolution of north-eastern Spain based on lake records has significantly increased during the last decade (e.g. Morellón et al., 2008; Corella et al., 2011a, 2013; Gutiérrez et al., 2013; Pérez-Sanz et al., 2013). However, continuous records since the late Pleistocene are restricted to a few lacustrine successions (for example, Portalet peatbog González-Sampériz et al., 2006; Lake Estanya Morellón et al., 2009a). Previously published numerical dates indicate that lacustrine deposition in the ITMC complex spans at least between $24 \mathrm{kyr}$ and 796 yr вр (Pellicer et al., 2014), covering the Late Glacial and Holocene rapid climatic oscillations in the north-eastern Iberian Peninsula. Previous studies in the area have included: (i) detailed geomorphological mapping, which allowed differentiation of the main tufa morphostratigraphic units in the ITMC (Linares et al., 2010a); and (ii) geophysical surveys using ground penetrating radar (GPR) which allowed characterization of the internal architecture of the tufa deposits (Pellicer et al., 2014). The GPR survey data were used to characterize non-rippable, lowconductivity, porous, lithified tufas located at the outer margins of the palaeolakes. However, radar signatures from high conductivity, low porosity, clay/silt-rich soft sediments deposited in the palaeolakes were poor or absent (Pellicer et al., 2014). Research on late Pleistocene tufa-dammed lakes is often based on limited exposures (for example, Pyramid Lake, USA; Benson et al., 1995) and/or sediment cores (for example, Taravilla Lake, Spain; Valero Garcés et al., 2008). Both of these approaches often fail to provide robust information on the geochronological relationships between the different stratigraphic units and facies. This limitation can be overcome partially through the application of the trenching technique that provides artificial exposures at selected locations. The trenches may allow detailed descriptions of the sedimentary units and the lateral facies changes, and permit the identification and characterization of deformation structures (e.g. McCalpin, 2009; Gutiérrez et al., 2013).

The objectives of this work are as follows: (i) testing the potential of trenching methods for the sedimentological characterization of lacustrine sediments; (ii) proposing a sedimentological model for the lakes developed within tufa mounds; (iii) expanding existing knowledge on 
the palaeoenvironmental conditions in the northeastern sector of the Iberian Peninsula during Late Glacial and Holocene times; and (iv) proposing a new hydrogeological evolutionary model for this unique tufa mound complex. Sediments exposed in the trenches excavated in the palaeolake depressions have been analysed by defining the main lithological units and facies types. Facies characterization is supported by geochemical analyses performed on sediments collected in trench T3, which displays the most complex stratigraphy and covers the longest time span.

To the knowledge of the present authors, with the exception of a single tufa mound reported in Poland (Gradzinski et al., 2001), this is the only tufa mound complex documented in Europe and the first time that palaeolakes associated with such a peculiar hydrological and geomorphic environment are analysed from a sedimentological perspective. Moreover, the studies in which lake deposits (for example, palaeolakes and lake terraces) have been investigated via trenching are very scarce (e.g. Gutiérrez et al., 2013).

\section{THE ISONA TUFA MOUND COMPLEX}

The Isona tufa mound complex (ITMC) is located in the east-west trending Tremp Basin within the central sector of the South-Pyrenean Zone. This structural zone of the Pyrenees comprises three main south-verging thrust sheets developed on Mesozoic and Cenozoic rocks, from north to south: Boixols-Sant Corneli, Montsec and Serres Marginals (Ardèvol et al., 2000; Barnolas \& Pujalte, 2004; Teixell, 2004). The Tremp Basin corresponds to an open syncline that constitutes the footwall of the Boixols-Sant Corneli Thrust to the north, and the hanging wall of the Montsec Thrust to the south (Rosell, 1996; Fig. 2A). The topographic depression, mainly developed by differential erosion, is bounded by the Boixols-Sant Corneli Range [1350 m above sea-level (a.s.l.)] to the north, the west-plunging Isona Anticline (1250 m a.s.l.) on the east, the Montsec Range to the south (1700 m a.s.l.) and the Noguera-Pallaresa River to the west (410 to $370 \mathrm{~m}$ a.s.l.).

The bedrock geology consists of three main hydrostratigraphic units from bottom to top (Fig. 1): (i) Late Cretaceous interstratified limestones and marls acting as an aquitard; (ii) the Late Cretaceous Areny-Montsec aquifer system, composed of up to $200 \mathrm{~m}$ of calcarenites of the Areny Formation, plus a number of underlying limestone units; (iii) a 60 to $400 \mathrm{~m}$ thick clay- rich impermeable unit of the Late CretaceousEarly Palaeocene Garumn Facies (Rosell et al., 2001) that confines the underlying ArenyMontsec karst aquifer. The Pleistocene deposits of the ITMC, developed in the main discharge area of the of the Areny-Montsec artesian aquifer, consist of several stepped morphostratigraphic units unconformably overlying the argillaceous bedrock of the Garumn Facies (Linares et al., 2010a; Pellicer et al., 2014; Fig. 2B).

The development of an artesian karstic aquifer in the Areny-Montsec hydrostratigraphic unit, confined by the overlying impermeable clays and marls of the Garumn Facies, is determined by the geology and erosional topography of the Tremp Basin (Linares, 1995). The main recharge areas of the aquifer are associated with outcrops of karstified carbonate and calcarenite rocks in the highrelief margins of the basin (Fig. 2A). The location of the discharge area is controlled by the concurrence of a structural high in the Areny-Montsec unit, a lateral facies change of that unit into less permeable marls, and faults associated with the structural high, acting as preferential pathways for the rising groundwater flow (Linares et al., 2010a). The Basturs Lakes and several springs located along the edges of the ITMC are perched above the drainage network and constitute the main active natural discharge points of the aquifer (Fig. 2B). The average recharge in the ArenyMontsec aquifer by rainfall infiltration is estimated at $8 \mathrm{hm}^{3} \mathrm{yr}^{-1}$, while the mean discharge in the Basturs Lakes is ca $3 \mathrm{hm}^{3} \mathrm{yr}^{-1}$ (Linares, 1995). The wells in the area show hydraulic heads as high as $3.5 \mathrm{~kg} \mathrm{~cm}^{-2}$ and the piezometric surface of the aquifer defines a dome-like geometry whose crest coincides with the centre of the ITMC (Linares et al., 2010a). The spring waters associated with the ITMC mostly correspond to the calcium-bicarbonate hydrochemical facies and are saturated with respect to calcite (Linares et al., 2010a).

The Pleistocene deposits of the ITMC constitute an outlier $c a 5 \mathrm{~km}^{2}$ in area. Geomorphological and stratigraphical relationships, together with radiocarbon and U/Th indicate that the ITMC is composed of three staircased morphostratigraphic tufa units (Linares et al., 2010b; Pellicer et al., 2014; Fig. 2B): the upper and older unit (Tufa 1) yielded minimum ages of $350 \mathrm{ka}$; a second unit (Tufa 2) provided ages between $>350 \mathrm{ka}$ and $214 \mathrm{ka}$; the third unit (Tufa 3) corresponds to tufas spatially associated with the active springs and comprises ages with a maximum bound at $110 \mathrm{ka}$. The upper tufa unit 
A

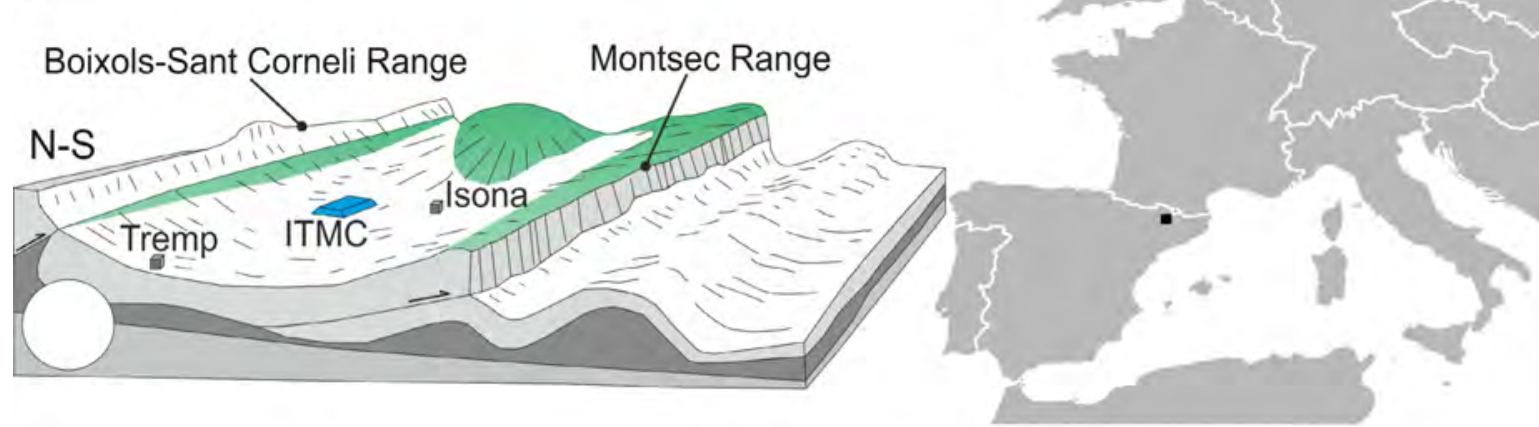

B

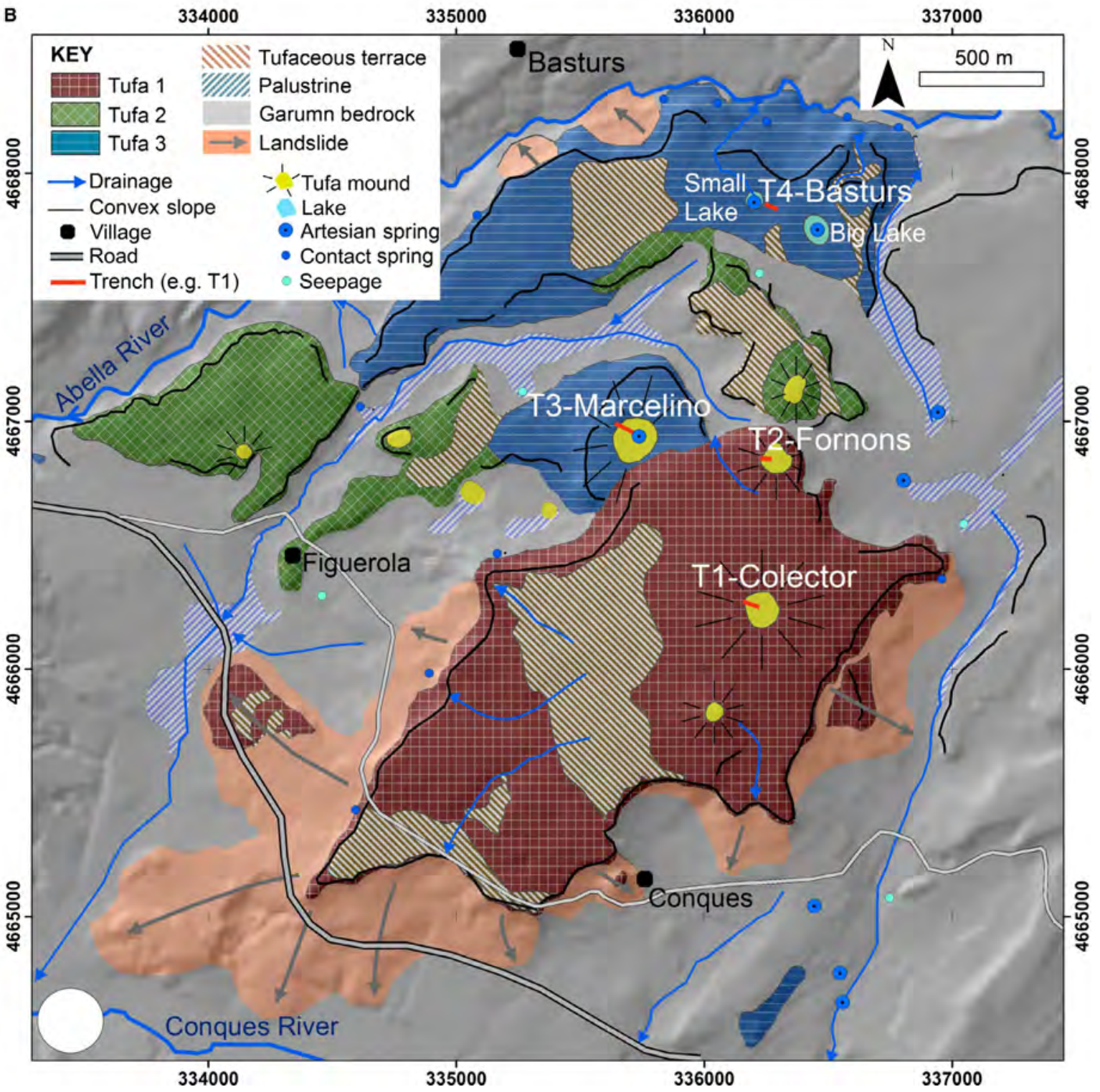

Fig. 2. (A) Study area located in the central sector of the Spanish Pyrenees. The Isona tufa mound complex (ITMC; in blue) occurs in the main discharge area of the Areny-Montsec artesian aquifer, developed within an open syncline between the Boixols-Sant Corneli and the Montsec mountain ranges. Main aquifer recharge areas (in green) are located on the high-relief margins of the basin. (B) Geomorphological units and aquifer discharge outlets of the ITMC and location of trenches excavated in Colector (T1), Fornons (T2) and Marcelino (T3) palaeolakes, as well as in the Basturs lakes (T4). 
(Tufa 1), over $45 \mathrm{~m}$ thick (Linares et al., 2010a), constitutes the caprock of a mesa, locally known as Mont de Conques, with a maximum elevation of $703 \mathrm{~m}$ a.s.l. It includes three fossil tufa mounds, in which pool, rimstone and slope facies, as well as large tufaceous terraces, can be identified. The second unit (Tufa 2) with an approximate thickness of 10 to $20 \mathrm{~m}$, also including fossil tufa mounds at altitudes ranging from 570 to 690 m.a.s.l., formed at a later stage north of the upper unit and as an apparently separate entity to the north-west. The tufas of the lower unit (Tufa 3), ca $10 \mathrm{~m}$ thick, are associated with the Marcelino palaeolake and the Basturs groundwater discharge lakes at altitudes ranging between $634 \mathrm{~m}$ and $647 \mathrm{~m}$ a.s.l. (Fig. 2B).

Sediments deposited in the depressions located in the centre of the tufa mounds were described by Pellicer et al. (2014) as pool facies consisting of fine-grained organic-rich soft carbonates. These palaeolakes are enclosed by annular rimstone facies, defined as compact carbonates with a concentric internal structure related to their vertical growth. Other facies associated with the development of tufa mounds are: vent facies composed of crystalline limestone precipitated along the spring conduit; palustrine/ lacustrine facies composed of carbonate muds

confined downstream by dams; dam facies developed by increasing turbulence along convex changes in slope; slope facies consisting of sinuous beds with step-like topography; and cascade facies associated with sharp changes in slope. Further details are given in Pellicer et al. (2014). Older tufa mounds have undergone extensive erosion, as illustrated by the presence of protruding vent facies at the surface (Linares et al., 2010a). At the present time, tufa deposition is limited to palustrine areas related to active discharge and to small-scale cascade and slope facies deposited from local springs controlled by the tufa-bedrock contact, exposed in the southern margin of the Abella River valley (Fig. 2B).

\section{METHODS}

Sediments deposited in the inner depression of tufa mounds were investigated via trenching (see location in Fig. 2). Four 46 to $74 \mathrm{~m}$ long and 1.5 to $3.0 \mathrm{~m}$ deep backhoe trenches with vertical walls and radial orientation were excavated. Three trenches were excavated from the edge to the centre of three palaeolakes (T1 in Colector, T2 in Fornons and T3 in Marcelino) and an additional one at the margin of one of

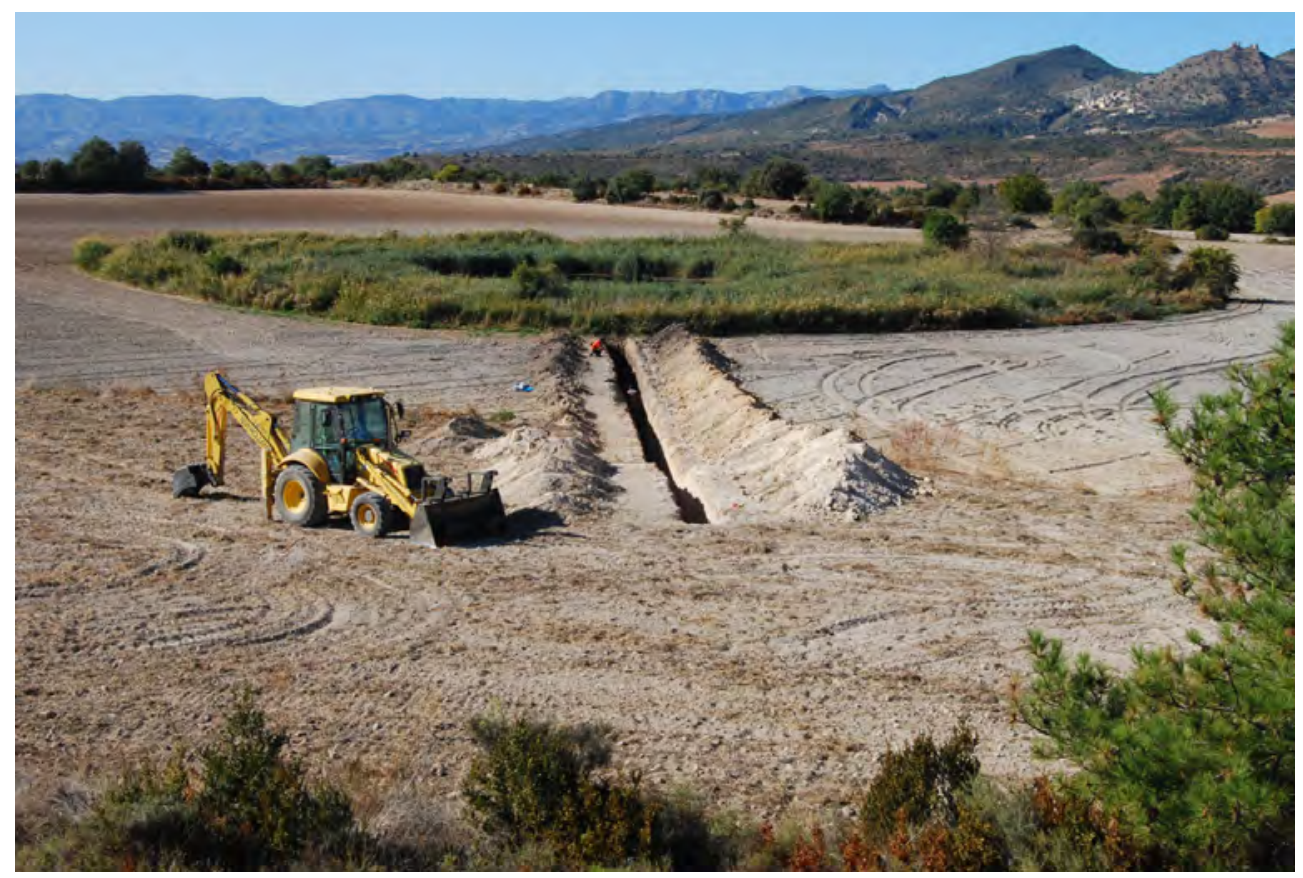

Fig. 3. View towards the north-west of trench T4 excavated with a radial orientation from the edge of the Basturs Small Lake. A reference orthogonal grid with a spacing of $1 \mathrm{~m}$ on the right wall of the trench (northern wall) was used for accurate logging of sedimentological and deformation structures. The excavator is $c a 6 \mathrm{~m}$ from the front to the back bucket.

(C) 2016 The Authors. Sedimentology (C) 2016 International Association of Sedimentologists, Sedimentology, 63, 1786-1819 
the active Basturs Lakes (T4; Fig. 3). The artificial exposures were used to directly characterize the deposits that fill the palaeolakes developed in the inner depressions of tufa mounds, corresponding to different morphostratigraphic units at three elevations: $700 \mathrm{~m}$ a.s.l. (T1 - Colector and T2 - Fornons), $650 \mathrm{~m}$ a.s.l. (T3 - Marcelino) and $630 \mathrm{~m}$ a.s.l. (T4 - Basturs Lakes). The stratigraphy and deformation structures exposed in one of the walls of each trench were mapped at 1:50 scale using a reference grid consisting of horizontal and vertical strings spaced $1 \mathrm{~m}$ apart. Sedimentary facies were described visually and by microscopic observations on smear slides.

Geochemical analyses were carried out in samples from trench T3 excavated in the Marcelino palaeolake, which exposed the longest and most complex sedimentary record. Sampling was performed at 10 to $20 \mathrm{~cm}$ intervals along four detailed logs evenly distributed within the logged trench wall. A total of 31 samples was analysed for Total Carbon (TC), Total Organic Carbon (TOC), Total Inorganic Carbon (TIC), Total Nitrogen (TN) and Total Sulphur (TS). The TC, TOC and TS contents were determined with a LECO SC 144 DR elemental analyser (LECO Corporation, St. Joseph, MI, USA). The TIC was obtained by subtracting TOC from TC. The TN content was determined using a VARIO MAX CN element analyser (Elementar Analysensysteme $\mathrm{GmbH}$, Hanau, Germany). In order to determine the concentration of major inorganic elements, samples were digested with $\mathrm{HNO}_{3}(9 \mathrm{ml})$ and $\mathrm{HCl}(3 \mathrm{ml})$ in a microwave oven 'BERGHOF MWS' (Berghof GmbH, Tübingen, Germany) and analysed by optical emission spectrometry using inductively coupled plasma - atomic emission spectroscopy (ICP-OES; Thermo ICP-OES iCAP 6300 DUO - Thermo Fisher Scientific, Waltham, MA, USA). A statistical analysis of the geochemical data set (Principal Component Analyses) was carried out using the sPSs 20.0 software, aimed at investigating the end-members that can help to infer the main environmental processes controlling sediment deposition (Table 1).

Samples for anisotropy of magnetic susceptibility radiocarbon and optically stimulated luminescence (OSL) dating were collected in trenches T1, T3 and T4 (Table 2). Priority was given to the oldest and youngest units of the exposed sequences, in order to bracket their age, and to stratigraphic horizons that record major depositional events like the change from lacustrine to detrital deposition related to the deactivation of the springs. Radiocarbon ages were
Table 1. Results of principal component analyses (PCA) carried out using the SPSS20.0 software aimed to investigate the end-members that aided inferring main environmental processes controlling sediment deposition.

\begin{tabular}{|c|c|c|c|c|}
\hline \multirow[b]{2}{*}{ Variable } & \multicolumn{2}{|c|}{ Component matrix } & \multicolumn{2}{|c|}{ Communalities } \\
\hline & PCA-EV1 & PCA-EV2 & Initial & Extraction \\
\hline $\mathrm{Al}$ & 0.99 & $0 \cdot 04$ & $1 \cdot 00$ & 0.99 \\
\hline As & $0 \cdot 82$ & $0 \cdot 18$ & $1 \cdot 00$ & $0 \cdot 70$ \\
\hline $\mathrm{Ba}$ & $1 \cdot 00$ & $0 \cdot 01$ & $1 \cdot 00$ & $0 \cdot 99$ \\
\hline $\mathrm{Ca}$ & -0.98 & $0 \cdot 12$ & $1 \cdot 00$ & 0.97 \\
\hline $\mathrm{Cd}$ & $0 \cdot 88$ & -0.08 & $1 \cdot 00$ & $0 \cdot 78$ \\
\hline Co & 0.97 & $0 \cdot 17$ & $1 \cdot 00$ & 0.96 \\
\hline $\mathrm{Cr}$ & 0.96 & $0 \cdot 18$ & $1 \cdot 00$ & 0.96 \\
\hline F.B & $0 \cdot 81$ & $0 \cdot 16$ & $1 \cdot 00$ & $0 \cdot 69$ \\
\hline F.C & -0.06 & $0 \cdot 46$ & $1 \cdot 00$ & $0 \cdot 21$ \\
\hline F.D & $0 \cdot 22$ & $0 \cdot 31$ & $1 \cdot 00$ & $0 \cdot 15$ \\
\hline F.E & $0 \cdot 29$ & $-0 \cdot 74$ & $1 \cdot 00$ & $0 \cdot 63$ \\
\hline F.F & -0.09 & $-0 \cdot 20$ & $1 \cdot 00$ & $0 \cdot 05$ \\
\hline F.G & -0.31 & $-0 \cdot 34$ & $1 \cdot 00$ & $0 \cdot 21$ \\
\hline F.H & $-0 \cdot 24$ & $0 \cdot 06$ & $1 \cdot 00$ & $0 \cdot 06$ \\
\hline F.I & $-0 \cdot 24$ & $0 \cdot 08$ & $1 \cdot 00$ & $0 \cdot 07$ \\
\hline $\mathrm{Fe}$ & 0.97 & $0 \cdot 13$ & $1 \cdot 00$ & 0.96 \\
\hline $\mathrm{K}$ & 0.99 & $0 \cdot 01$ & $1 \cdot 00$ & 0.98 \\
\hline $\mathrm{Mg}$ & 0.98 & 0.05 & $1 \cdot 00$ & 0.96 \\
\hline $\mathrm{Mn}$ & 0.95 & $0 \cdot 15$ & $1 \cdot 00$ & $0 \cdot 92$ \\
\hline $\mathrm{Na}$ & 0.99 & -0.03 & $1 \cdot 00$ & 0.97 \\
\hline $\mathrm{Ni}$ & 0.98 & $0 \cdot 12$ & $1 \cdot 00$ & 0.97 \\
\hline $\mathrm{P}$ & $0 \cdot 71$ & -0.57 & $1 \cdot 00$ & 0.83 \\
\hline $\mathrm{Pb}$ & 0.93 & 0.03 & $1 \cdot 00$ & $0 \cdot 86$ \\
\hline $\mathrm{Si}$ & 0.03 & $0 \cdot 54$ & $1 \cdot 00$ & $0 \cdot 30$ \\
\hline $\mathrm{Sr}$ & $-0 \cdot 88$ & $0 \cdot 21$ & $1 \cdot 00$ & $0 \cdot 81$ \\
\hline $\mathrm{Ti}$ & 0.98 & 0.06 & $1 \cdot 00$ & 0.97 \\
\hline TIC & -0.99 & 0.09 & $1 \cdot 00$ & 0.99 \\
\hline $\mathrm{TN}$ & -0.07 & $-0 \cdot 84$ & $1 \cdot 00$ & $0 \cdot 71$ \\
\hline TOC & $0 \cdot 70$ & $-0 \cdot 42$ & $1 \cdot 00$ & $0 \cdot 66$ \\
\hline $\mathrm{TS}$ & $0 \cdot 15$ & $0 \cdot 18$ & $1 \cdot 00$ & 0.06 \\
\hline $\mathrm{Zn}$ & 0.99 & -0.07 & $1 \cdot 00$ & 0.98 \\
\hline $\mathrm{Zr}$ & 0.97 & 0.04 & $1 \cdot 00$ & 0.94 \\
\hline
\end{tabular}

Total variance

Initial eigenvalues

\begin{tabular}{lrrl}
\cline { 2 - 4 } Component & Total & \% of variance & Cumulative \% \\
\hline 1 & $19 \cdot 475$ & $60 \cdot 86$ & $60 \cdot 86$ \\
2 & $2 \cdot 811$ & $8 \cdot 79$ & $69 \cdot 64$ \\
\hline
\end{tabular}

calibrated using the software package OxCal 4.2 and the data set IntCal 13 of Reimer et al. (2013). An age-depth model for the composite log of trench T3 was obtained by linear interpolation in each sedimentological profile using the Analyseries software. Optically stimulated luminescence ages on aeolian quartz grains from two samples collected in trench $\mathrm{T} 1$ were calculated 
Table 2. Summary of radiocarbon and optically stimulated luminescence (OSL) dates with error margins at 1 sigma. Location of samples is shown in Figs 5, 7 and 8. Radiocarbon samples T4-C1, T4-C2, T4-C3 and T4-C4 were presented previously in Pellicer et al. (2014). Radiocarbon samples obtained for this work were analysed in the Beta Analytic Inc. Laboratory, Miami, FL, USA. Calibrated ages were calculated with the software package OxCal 4.2 and the data set IntCal 13 (Reimer et al., 2013). MIS = marine isotope stage.

\begin{tabular}{|c|c|c|c|c|c|c|}
\hline Sample & $\begin{array}{l}\text { Dating } \\
\text { method }\end{array}$ & Material & 14С yr вР & Calibrated yrs вр & Stage & Facies type \\
\hline T1-MC3 & $\mathrm{C}^{14}$ & Charcoal & $1150 \pm 30$ & 1174 to 979 & $\begin{array}{l}\text { Medieval } \\
\text { Warm Period }\end{array}$ & Colluvial \\
\hline T1-OSL I & OSL & Quartz & & 16880 to 14200 & Oldest Dryas & Aeolian/Colluvial \\
\hline T1-OSL II & OSL & Quartz & & 20225 to 17605 & MIS 2 (AS-2b) & Aeolian/Colluvial \\
\hline T1-MC1 & $\mathrm{C}^{14}$ & Organic sediment & $23120 \pm 110$ & 27640 to 27192 & MIS 3 (AL-4) & Palustrine \\
\hline T3-MAR1 & $\mathrm{C}^{14}$ & Organic sediment & $1770 \pm 30$ & 1812 to 1605 & $\begin{array}{l}\text { Dark Ages } \\
\text { Cooling Period }\end{array}$ & Organic \\
\hline T3-MAR6 & $\mathrm{C}^{14}$ & Organic sediment & $3790 \pm 30$ & 4258 to 4085 & Subboreal & Organic \\
\hline T3-MAR9 & $\mathrm{C}^{14}$ & Organic sediment & $6090 \pm 40$ & 7032 to 6850 & Atlantic & Organic \\
\hline T3-MAR10 & $\mathrm{C}^{14}$ & Organic sediment & $7940 \pm 40$ & 8982 to 8641 & Boreal & Palustrine \\
\hline T3-MAR11b & $\mathrm{C}^{14}$ & Organic sediment & $11200 \pm 50$ & 13178 to 12970 & Bølling-Allerød & Aeolian/Colluvial \\
\hline T3-MAR13 & $\mathrm{C}^{14}$ & Organic sediment & $18150 \pm 90$ & 22304 to 21758 & MIS 2 (AS-2c) & Aeolian/Colluvial \\
\hline $\mathrm{T} 4-\mathrm{C} 1$ & $\mathrm{C}^{14}$ & Charcoal & $985 \pm 30$ & 960 to 894 & $\begin{array}{l}\text { Medieval } \\
\text { Warm Period }\end{array}$ & Organic \\
\hline T4-C2 & $\mathrm{C}^{14}$ & Charcoal & $3220 \pm 35$ & 3511 to 3372 & Subboreal & Organic \\
\hline $\mathrm{T} 4-\mathrm{C} 4$ & $\mathrm{C}^{14}$ & Charcoal & $15470 \pm 90$ & 18911 to 18551 & MIS 2 (AS-2b) & Organic \\
\hline T4-C3 & $\mathrm{C}^{14}$ & Charcoal & $20120 \pm 130$ & 24512 to 23870 & MIS 2 (AS-3) & Organic \\
\hline
\end{tabular}

in the Luminescence Dating Research Laboratory of the University of Illinois - Chicago (Table 3). Sampling was performed with opaque PVC tubes inserted horizontally into the sediment and subsequently sealed to avoid light exposure. Bulk samples were collected from the surroundings of each sampling point for dose rate determination. Details on the OSL dating data and procedure are presented in Table 3. The numerical ages helped to partially reconstruct the chronological evolution of the artesian spring system, to infer the timing of depositional changes attributable to climate variability, and to constrain deformation events and estimate sedimentation rates.

\section{RESULTS}

Descriptions of stratigraphic units and subunits for each trench are presented in chronological order of deposition. Units are named using the suffixes Co for trench T1 (Colector), Fo for trench T2 (Fornons), Ma for trench T3
(Marcelino) and Ba for trench T4 (Basturs Lakes), followed by a figure indicating the unit number and a letter to designate the subunit.

\section{Trench 1 - Colector}

A $59 \mathrm{~m}$ long backhoe trench with a maximum depth of $3.2 \mathrm{~m}$ and a N106E orientation was excavated from the western edge of the Colector palaeolake towards its centre (Trench T1 in Fig. 2B). The depth of the trench was restricted by a highly indurated non-rippable carbonate unit (Co1d) between the vertical reference lines 23 and 43 (Fig. 4). The Colector tufa mound, representing the highest and oldest morphostratigraphic tufa unit at $700 \mathrm{~m}$ a.s.l. (Fig. 2), consists of an annular rimstone that encloses a circular palaeolake depression $150 \mathrm{~m}$ in diameter. The exposed strata in the palaeolake infill show a general inward dip $\left(6^{\circ}\right.$ to $\left.12^{\circ}\right)$ that increases in the central sector of the basin and shows an offlap arrangement from reference line 40 eastward (Fig. 4).

The units mapped can be divided into two sedimentary packages (Units Co1 and Co2) 


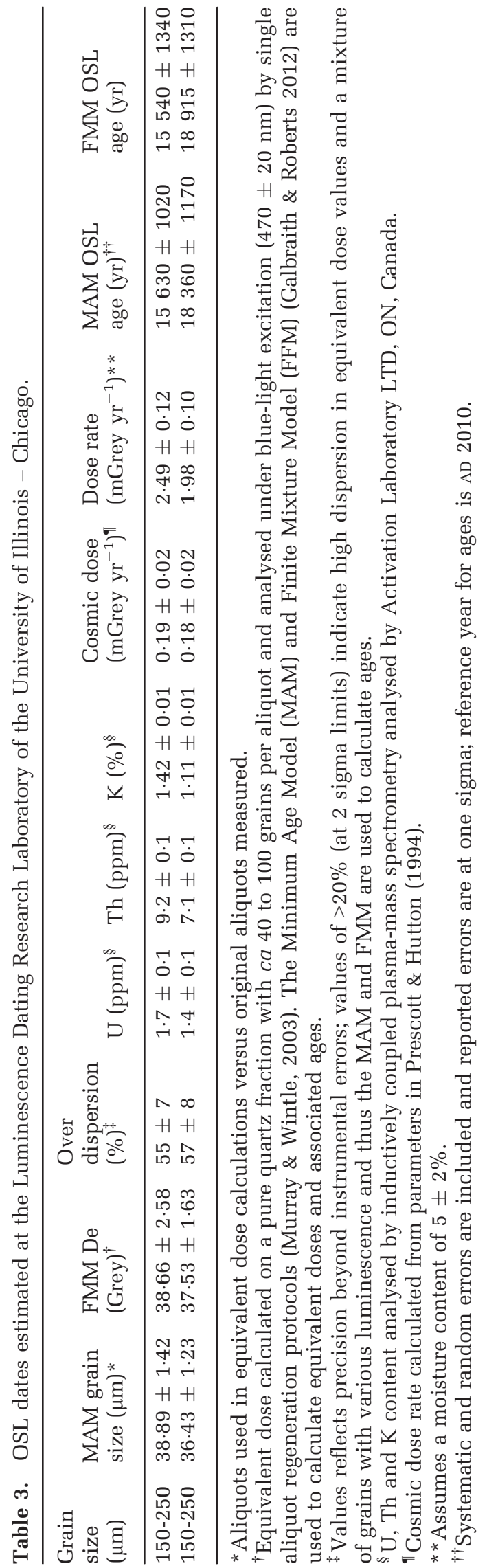

bounded by an angular unconformity and with markedly different sedimentological features (Fig. 4). The lower package (unit Co1) corresponds to late Pleistocene lake sediments composed of carbonate-rich deposits comprising three soft-sediment beds (Co1a, Co1b and Co1c), overlain at vertical reference lines 20 to 23 by an indurated layer (Co1d; Fig. 4). Subunits Co1a and Co1c are composed of massive to crudely bedded grey-beige carbonate silts with secondary carbonate and some bioturbation. Subunit Co1b consists of ochre-beige carbonate silt with scattered subangular granule-sized intraclasts and secondary carbonate. Subunit Co1d is a highly indurated carbonate rock composed of granule-sized rounded intraclasts with a strongly cemented silty matrix. These inward dipping lake sediments located in the outer zone of the palaeolakes are truncated by an erosional surface. Unit $\mathrm{Co1}^{\prime}$, located in the central sector of the lake, consists of two subunits $\left(\mathrm{Co}^{\prime} \mathrm{a}^{\prime}\right.$ and Co1b') with composition akin to Co1a and Co1b, respectively. This unit displays conspicuous soft-sediment deformation as revealed by the highly convoluted contact between both subunits. Subunit Co1a', displaying flame-like structures with amplitudes as high as $75 \mathrm{~cm}$, locally intrudes upward into subunit Co1b' (Fig. 4).

The late Pleistocene-Holocene upper package (Co2) consists of massive reddish fine-grained and gravelly deposits. In the central sector of the palaeolake, the base of this upper package is marked by a gravel bed that truncates the softsediment deformation structures in the underlying unit. Moreover, the top of unit $\mathrm{Co}^{\prime}$ shows a number of extensional tapering-downward fissures cross-cutting the soft-sediment deformation and filled with the basal gravelly unit of the upper package (Fig. 4A).

Unit Co2 is a detrital deposit composed of five subunits. Subunit Co2a consists of matrix-supported subrounded pebble gravel and orangebrown clayey silt. Its erosional base unconformably truncates the deformed underlying unit Co1'. Subunit Co2b is composed of massive orange-brown quartz-rich clayey silt with scattered subrounded granule-pebble gravel. Subunit Co2c consists of a clast-supported gravel bed pinching out towards the lake centre. Subunits Co2d and Co2e, at the top of the sequence, are bioturbated reddish silt-clay with scattered granule-sized intraclasts. Both thicken towards the palaeolake centre, especially subunit Co2d. The basin fill is overlain by a 10 to $50 \mathrm{~cm}$ thick soil related to ploughing and cultivation. 

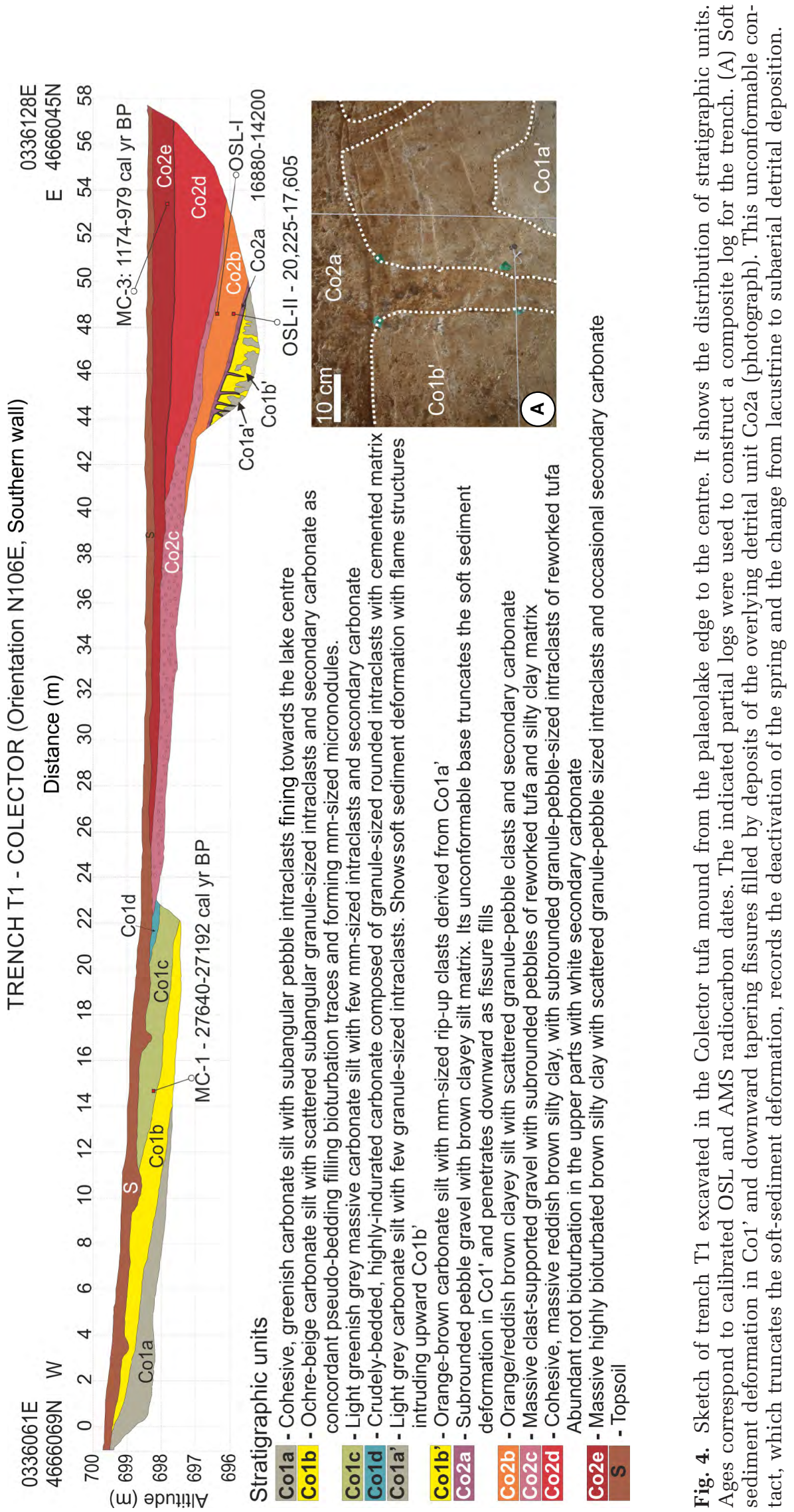

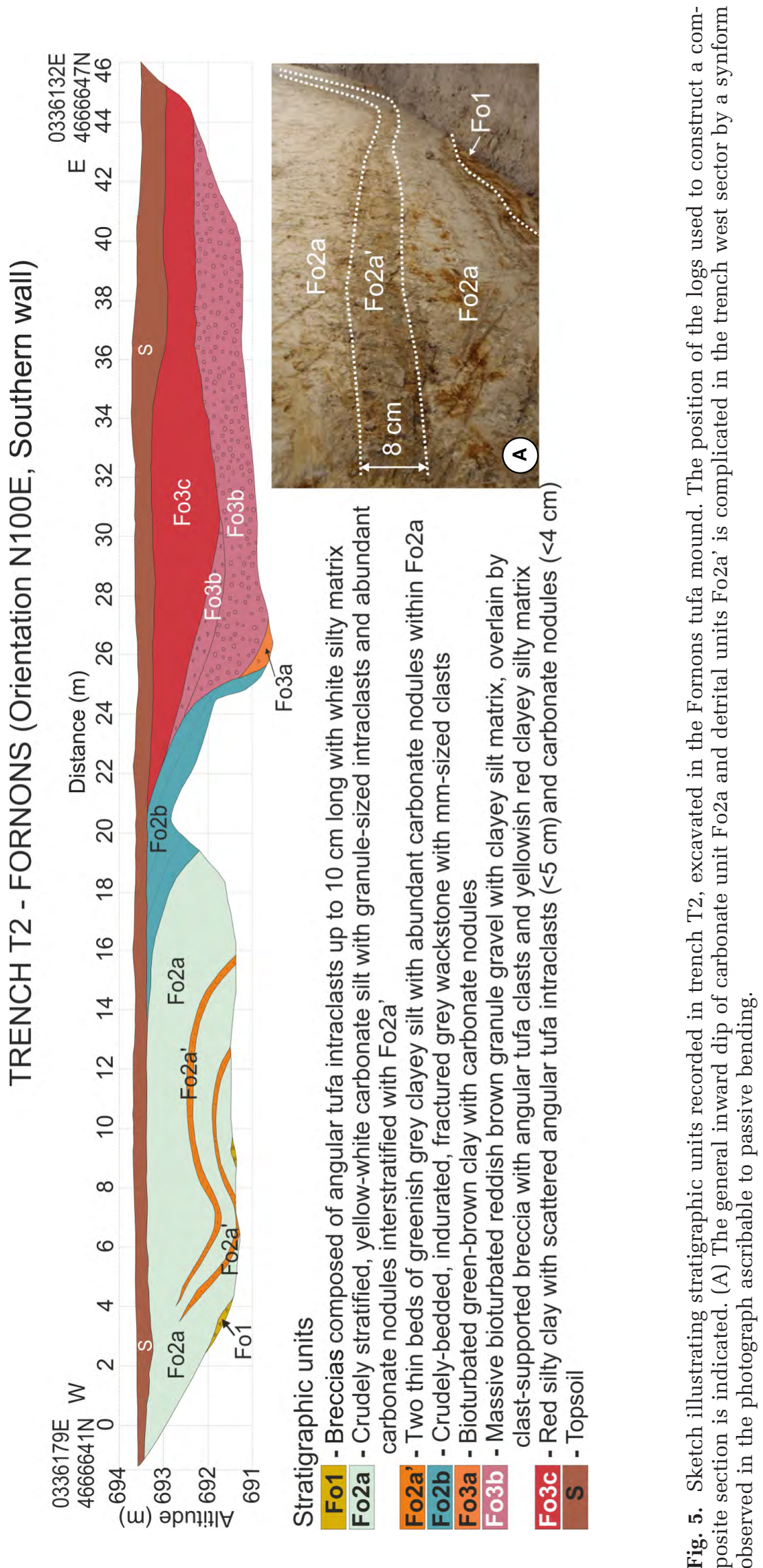


\section{Trench 2 - Fornons}

The Fornons tufa mound is located in the oldest morphostratigraphic unit (Tufa 1) at $693 \mathrm{~m}$ a.s.l. It encloses a circular palaeolake $110 \mathrm{~m}$ in diameter expressed in the landscape as a shallow depression surrounded by an annular ridge of rimstone facies. A $46 \mathrm{~m}$ long and $3 \mathrm{~m}$ deep backhoe trench with a N100E orientation was excavated from the edge to the centre of the palaeolake (T2 - Fig. 1). The excavation depth was restricted in the central sector of the trench by a highly indurated carbonate bed (Fo2b). Three main units have been differentiated (Fig. 5). These deposits are overlain along the whole trench by a 40 to $70 \mathrm{~cm}$ thick reddish black, organic-rich clayey agricultural soil with angular clasts.

Two sedimentary packages with contrasting sedimentology are differentiated. The lower one (units Fo1 and Fo2), exposed in the western sector of the trench (outer zone), essentially corresponds to carbonate-rich deposits with a general dip towards the centre of the basin, interstratified with detrital beds and overlain by indurated carbonates. The top of this package corresponds to an erosional surface. The general inward dip of the strata is complicated in the marginal sector of the lake by a synform and an antiform $>1.4 \mathrm{~m}$ and $>1.0 \mathrm{~m}$ in structural relief, respectively. In the eastern limb of the antiform, beds dip as much as $30^{\circ}$ into the lake basin. The upper package (unit Fo3), overlying the former with an offlap arrangement, is dominated by detrital deposits.

Unit Fo1, exposed at the base of the western portion of the trench, consists of clast-supported detrital breccias with clay-silt matrix related to the reworking of the marginal rimstone. Unit Fo2 comprises two subunits with markedly different texture. Subunit Fo2a, composed of carbonate interstratified with two thin detrital beds, was deposited in the nearshore sector and is affected by folding. The carbonates consist of highly bioturbated yellow-white silt with granule-sized intraclasts showing evidence of pre-exisiting banding largely obliterated by bioturbation and pedogenic overprinting (i.e. secondary carbonate acummulation). These are interstratified with two beds 10 to $15 \mathrm{~cm}$ thick consisting of greenish grey clayey silt pinching out towards the margin at vertical reference line 4 (Fig. 5). These sediments are overlain by subunit Fo2b consisting of highly indurated, crudely bedded and fractured grey wackstone steeply dipping towards the lake centre.
Unit Fo3, overlying subunit Fo2b with an offlap relationship, consists of three subunits composed of detrital facies. Subunit Fo3a is a soft highly bioturbated clay with carbonate nodules. Subunit Fo3b is composed of reddish bioturbated clayey granule gravel overlain by clayey silty clast-supported breccia with angular tufa clasts. Subunit Fo3c, conformably overlying the latter, is composed of red silty clay with scattered angular tufa intraclasts and carbonate nodules.

\section{Trench 3 - Marcelino}

The Marcelino tufa mound is located in the youngest morphostratigraphic unit (Tufa 3) at $650 \mathrm{~m}$ a.s.l. (Fig. 2). It encloses a subcircular palaeolake depression $190 \mathrm{~m}$ in diameter with surface inclination towards the centre. The edges of the lake basin, adjacent to Tufa 1, correspond to a hillside underlain by slope-cascade tufa facies of the Colector tufa mound on the southeast, and the peripheral rimstone ridge of the tufa mound on the north and west. A $74 \mathrm{~m}$ long and $3.5 \mathrm{~m}$ deep backhoe trench with a N113E orientation was excavated from the northwestern margin of the palaeolake to the central and deepest point of the depression (T3 - Fig. 2). The excavation was carried out in a crop field with a spring in its centre, whose water is collected by a well and artificially drained towards the west margin of the tufa mound via an underground pipe. This drainage system maintains the piezometric level at a maximum elevation of $648 \mathrm{~m}$ a.s.l.

The five stratigraphic units exposed along the trench show a general dip of less than $5^{\circ}$ towards the centre of the depression and an overall offlap arrangement, with the oldest units in the marginal sector. These geometrical features determine that the trench, just $3.5 \mathrm{~m}$ deep, exposes a stratigraphic succession with an aggregate thickness of $5.9 \mathrm{~m}$, as measured on four detailed logs distributed along the trench (Fig. 6).

Unit Ma1 corresponds to highly indurated carbonates interpreted as rimstone grading laterally into breccia with ochre sandy silty matrix related to the erosion of the former and dipping towards the depression. This breccia is onlapped by unit Ma2, the oldest lake deposit exposed in the trench, which is composed of alternating detrital and carbonate-rich layers and shows a cumulative wedge-out arrangement. Subunit Ma2a consists of massive detrital clayey silt with an intercalated bed of bioturbated carbonate-rich silty clay. Subunit Ma2b, extending 


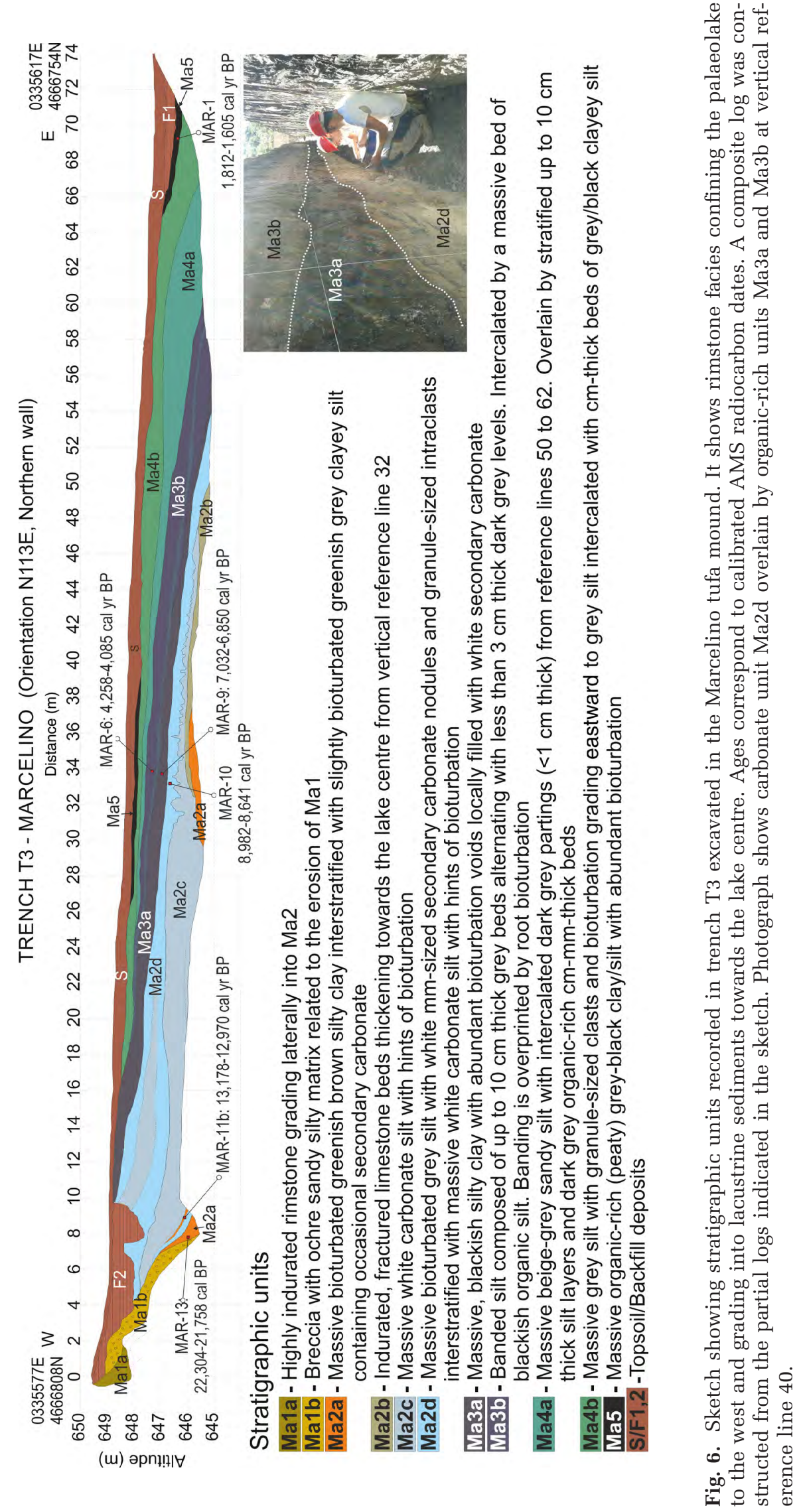


from vertical reference lines 32 to 50 (Fig. 6), is composed of massive indurated and fractured limestone thickening towards the lake centre and overlain by Ma2c. The latter, consisting of massive white carbonate silt, is overlain by Ma2d, composed of fine-grained carbonate facies with a variable degree of bioturbation and with secondary carbonate micronodules. East of the vertical reference line 30 (Fig. 6), this bed overlies subunit Ma2c with a highly distorted contact, showing decimetre-scale soft-sediment deformation including flame structures.

Subunit Ma3a, consisting of organic-rich, massive to banded silt and clays, grades laterally into banded silt and upward into carbonate lake sediments (Ma3b). The latter is overlain by a bed of banded organic-rich silts overprinted by root bioturbation and including a number of allochthonous sandstone pebbles more than $10 \mathrm{~cm}$ long, most probably related to human activity in the area. Unit Ma4, overlying unit Ma3 with an offlap relationship, comprises subunit Ma4a corresponding to banded to laminated, organic-rich sandy silt, grading upward and towards the lake centre into subunit Ma4b; this is composed of carbonate lake sediments, including littoral massive grey silts with granules that grade distally into laminated silts towards the lake centre. Unit Ma5 is a thin layer preserved between vertical reference lines 26 and 38, as well as 65 and 72 (Fig. 6), composed of massive organic-rich (peaty) grey-black clay. An anthropogenic fill designated as F1 was recorded in the central sector of the lake. Between vertical reference lines 0 and 10 (Fig. 6), the natural sediments are truncated by a man-made excavation backfilled with rubble; F2. A 10 to $40 \mathrm{~cm}$ thick agricultural soil overlies all of the units.

The lake deposits described show a cumulative wedge-out arrangement. The top of subunit Ma2a shows an inward dip of $15^{\circ}$ in the western sector of the lake. This general structure shows two local deviations. (i) Subunit Ma2a is affected by a marginal synform between the vertical reference lines 6 and 34 (Fig. 6), which is attenuated in subunit Ma2c, as illustrated by its increase in thickness towards the centre of the structure. (ii) The Holocene deposits exposed in the eastern portion of the depression (Units Ma3 and Ma4) show a general increase in thickness towards the centre and an obvious steepening in the inward dip east of the vertical reference line 60 (Fig. 6) suggesting higher subsidence in the central sector of the depression.

\section{Trench 4 - Basturs Lakes}

A $55 \mathrm{~m}$ long and up to $3.2 \mathrm{~m}$ deep trench with a $\mathrm{N} 110 \mathrm{E}$ orientation (imaginary line connecting the centre of the Basturs Small and Big lakes) was excavated (see location in Fig. 2). The trench excavation runs from the eastern margin of the Small Lake (Fig. 3) towards the Big Lake. The excavation was carried out in a crop field, which is affected by subsidence during periods of low water level in the lake. Here, differential subsidence is expressed as fissures, scarplets and gentle sags with concentric distribution.

A truncated and buried rimstone (subunit Ba1a) composed of low porosity, massive and indurated carbonate was mapped at vertical reference lines 20 to 22 (Fig. 7). At some point in time this tapering upward rimstone separated two depressions situated at different elevations, acting as the marginal barrier for a palaeodepression to the east, associated with the Big Lake. It also confined deposition in the Small Lake basin to the west (Fig. 7). The compact rimstone facies grades laterally on both sides to subunits Ba1b and Ba1c dipping away from the rimstone axis. Subunit Ba1b consists of a calcareous breccia grading eastward into massive silty sand with granule-sized tufa intraclasts. Subunit Ba1c, dipping to the west away from the rimstone, is composed of calcareous breccias interstratified with carbonate (sandy/clayey) silt with abundant bioturbation, and granule intraclasts topped by an oxidized layer indicating an episode of lake regression.

The sedimentary package comprising subunits $\mathrm{Ba} 2$ and $\mathrm{Ba} 3$, with a general dip of $\mathrm{Ca} 5^{\circ}$ to the east, corresponds to the deposits accumulated in the palaeodepression situated east of the rimstone (Ba1a). Subunit Ba2 includes a series of layers of carbonate-rich sediments interstratified with organic-rich beds. This subunit is composed of greyish silty sand with abundant granule-sized intraclasts overlain by organic-rich silty clay. Subunit Ba2a displays a range of softsediment deformations developed in clayey silts and sands, including fluid-escape and flame structures, as well as metre-scale convolute bedding and small dykes intruding into the overlying sediments (see photograph in Fig. 7). Subunit Ba2b comprises from bottom to top: (i) detrital tufas grading eastward into silty sand; (ii) a thin organic-rich clay layer with centimetre-scale flames intruding into the overlying bed - this layer grades laterally into carbonate-rich sand with granule-sized clasts and thickens 


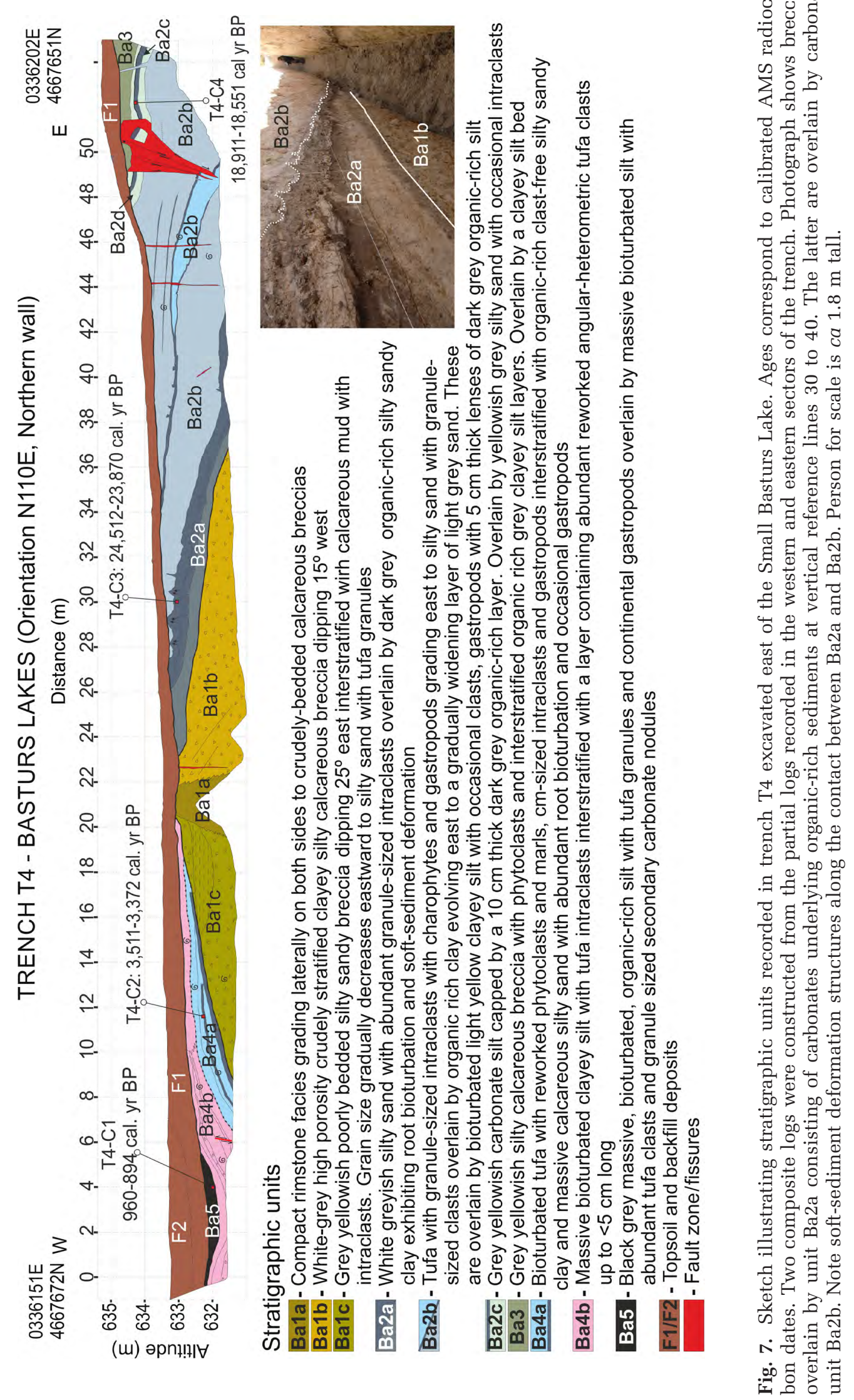




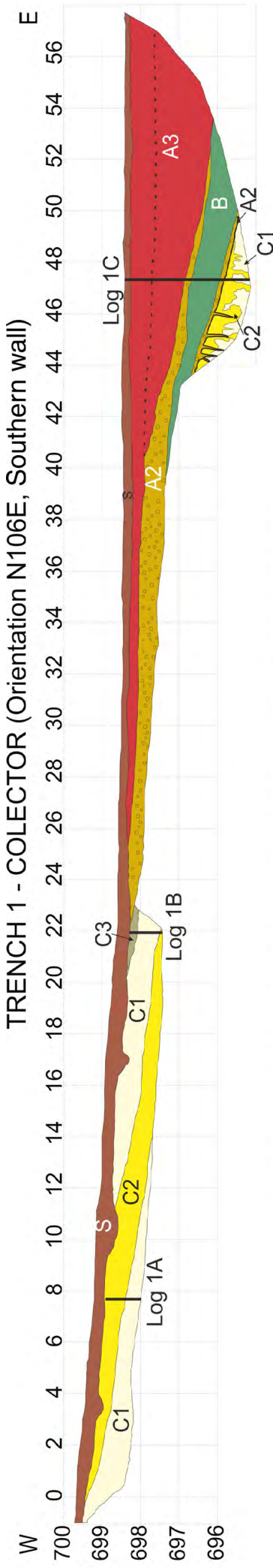

(u) әрпџ! I†

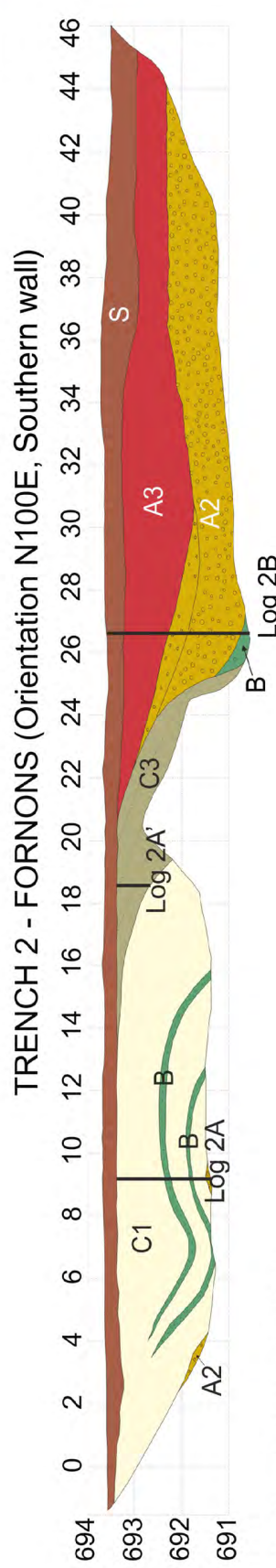

(u) әрn+!!ा

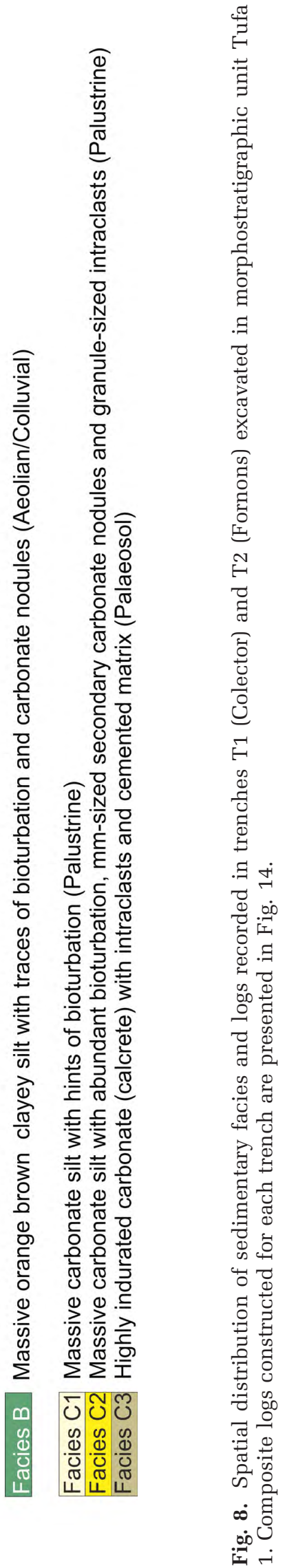




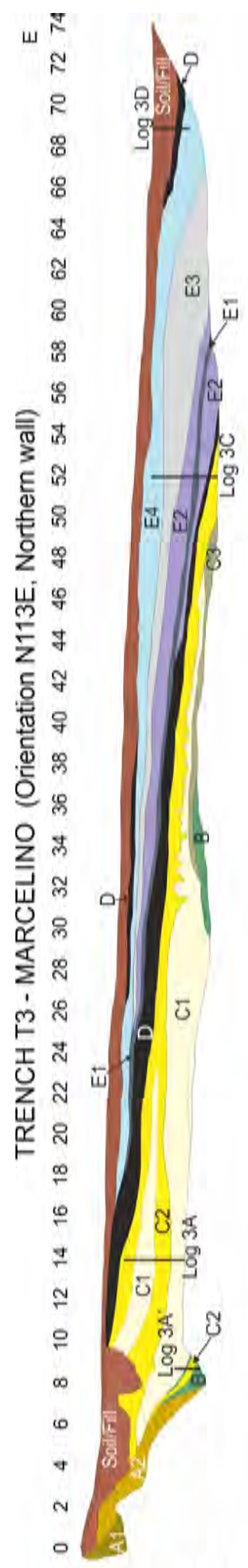

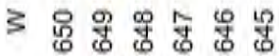

(u) өpnџ!lष

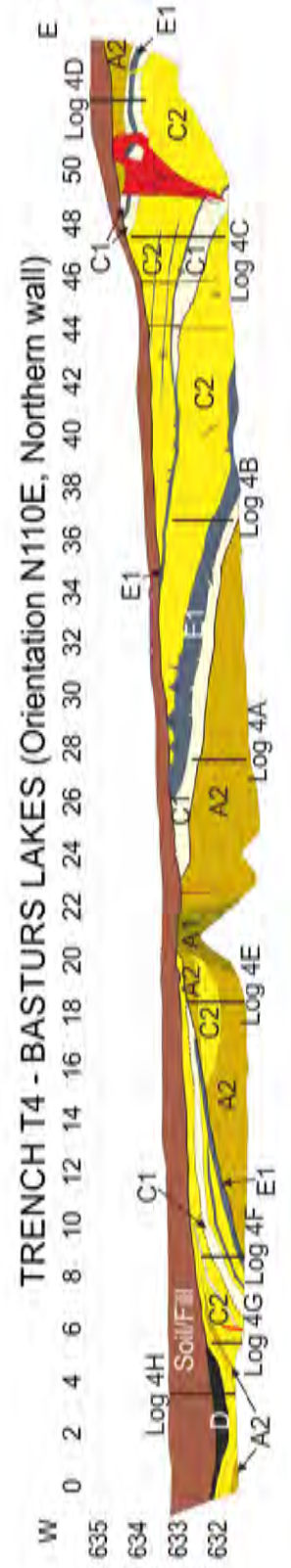

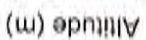

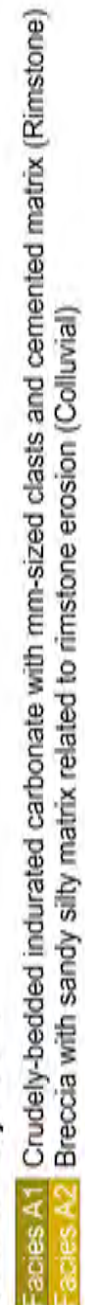

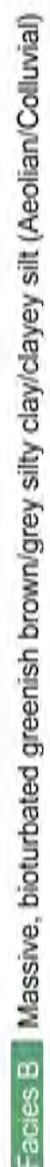

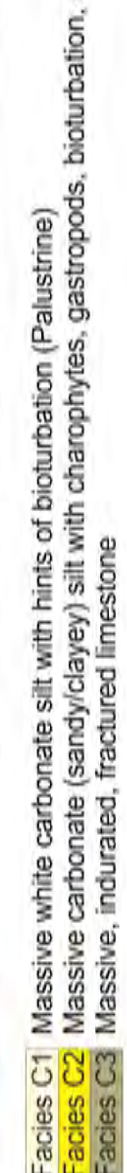

高

동
节

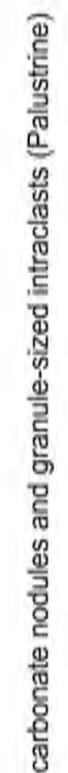

营

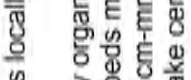

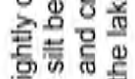

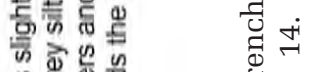

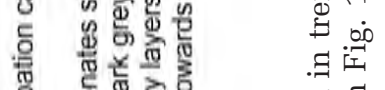

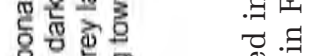

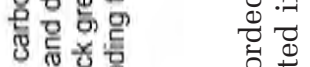

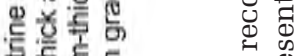

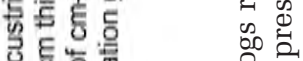

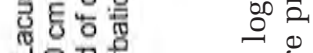

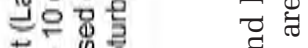

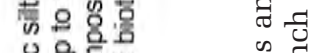

을을듬뭉

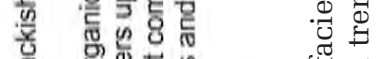

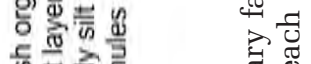

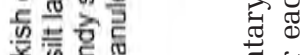

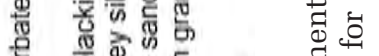

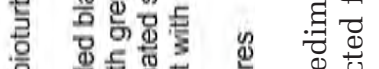

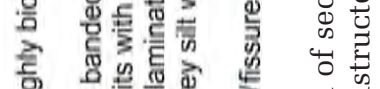

言

ब1

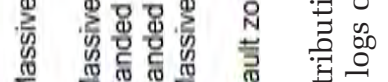

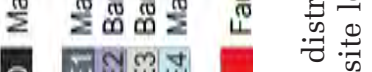

-

$\dot{\theta} \dot{\theta}$

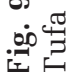




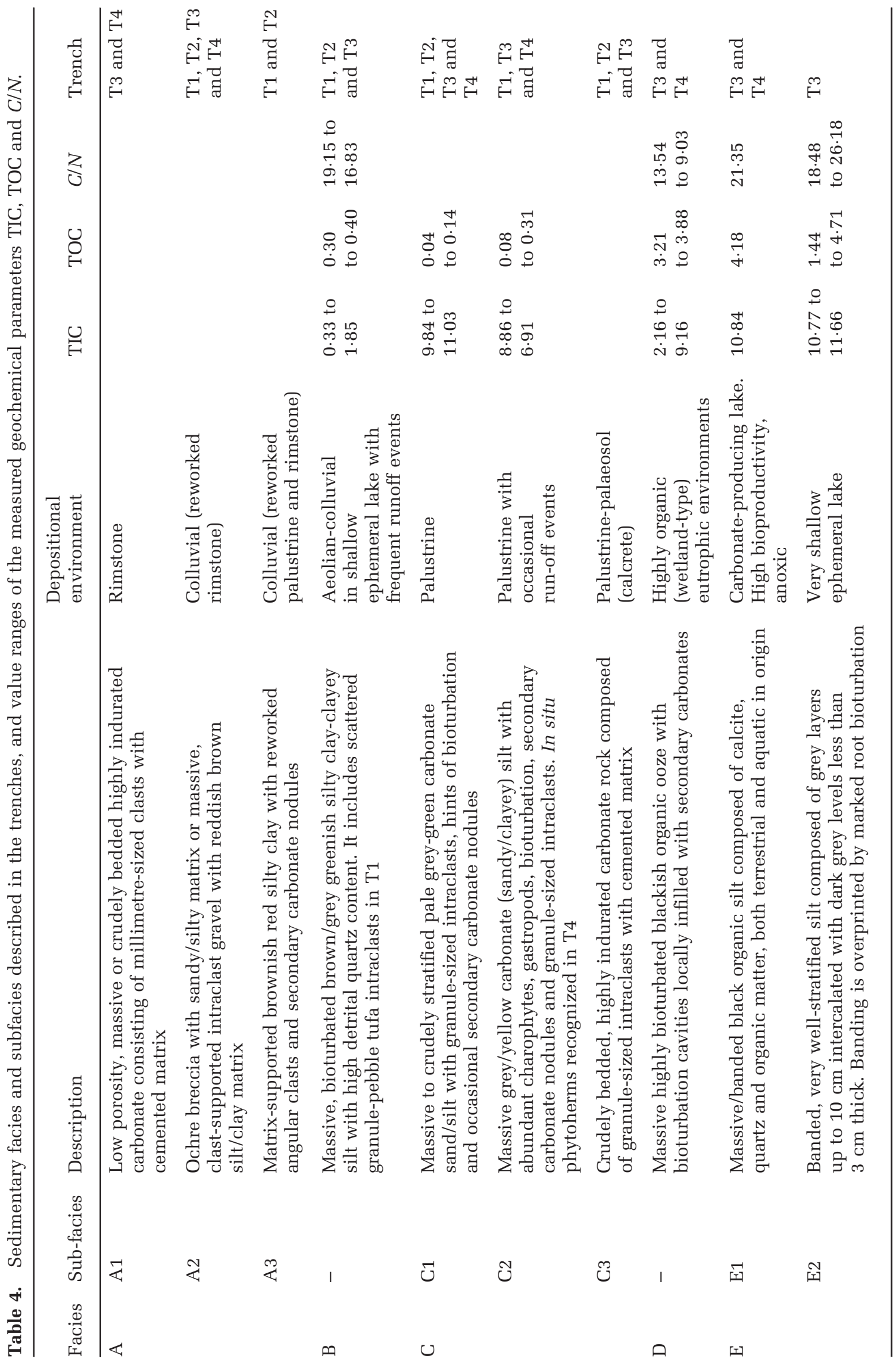


towards the lake centre; and (iii) light yellow clayey silty tufas including two 3 to $4 \mathrm{~cm}$ thick organic-rich clay lenses. Subunit Ba2c, overlying the latter, comprises a carbonate silt bed overlain by a $10 \mathrm{~cm}$ thick dark grey organic-rich layer grading upward into silty sand with occasional carbonate intraclasts. The top of subunit $\mathrm{Ba} 2 \mathrm{C}$ indicates that the rimstone, before the truncation of its upper part, was at least $1.4 \mathrm{~m}$ higher. Unit Ba3 is composed of calcareous silty breccia capped by a 5 to $7 \mathrm{~cm}$ thick light grey layer of clast-free clayey silt.

The sedimentary package comprising units $\mathrm{Ba} 4$ and $\mathrm{Ba} 5$, unconformably overlying Ba1c, corresponds to the deposits accumulated in the marginal sector of the Small Lake depression. These sediments record deposition confined by the rimstone and presumably during periods when the lake covered a larger area than at the present time. Beds of unit Ba4 show a general onlap relationship recording a rising lake water level. Conversely, Unit Ba5, with an offlap relationship, seems to be related to a regressive period. Unit Ba4 comprises 13 layers mostly composed of carbonate sediments, often including tufa intraclasts and continental gastropods. These are interstratified with some beds of reworked tufas with angular intraclasts and organic-rich clast-free facies. Subunit Ba4a consists of bioturbated tufa with reworked phytoclasts and marls, centimetre-sized intraclasts and gastropods interstratified with organic-rich clast-free silty sandy clay and massive calcareous silty sand with abundant root bioturbation and occasional gastropods. Subunit Ba4b is composed of massive bioturbated clayey silt with tufa intraclasts interstratified with a layer containing abundant reworked angular and heterometric tufa clasts up to $5 \mathrm{~cm}$ long. Unit Ba5 consists of massive black-grey bioturbated organic-rich silt with granule-sized intraclasts and terrestrial gastropods.

All of the units described above are overlain through an erosional contact by two recent manmade fills up to $1.2 \mathrm{~m}$ thick (Units F1 and F2): F1 consists of highly disturbed tufas related to agricultural activity; F2 corresponds to a fill dumped 25 to 30 years ago to counterbalance ground subsidence at the lake margin. A number of deformation structures are observed in the trench. The succession east of the rimstone is tilted $\mathrm{Ca} 5^{\circ}$ to the east and displays several fissures and a fault zone between vertical reference lines 49 and 51 (Fig. 7). The fault zone corresponds to a west-dipping, down to the east 
oversteepened normal fault, which has probably been rotated due to the aforementioned eastward tilting. The fault splays upward grading into a complex deformation zone with breccias and fissures. The tilted beds record a minimum vertical displacement of $1.6 \mathrm{~m}$, assuming that the base of the organic-rich deposits in subunit Ba2a was deposited horizontally. The normal fault accommodates a vertical displacement of $0.5 \mathrm{~m}$ as measured on the thin organic-rich layer in subunit $\mathrm{Ba} 2 \mathrm{~b}$ at vertical reference line 49 (Fig. 7). The late Holocene subunits Ba4b and Ba5, west of the rimstone, display a synformal structure and a small synthetic normal fault on the eastern limb. This structure records differential subsidence with a minimum vertical displacement of $1.4 \mathrm{~m}$. It is likely that a significant part of the deformation occurred after deposition of unit 5 , as suggested by the $c a$ $1.2 \mathrm{~m}$ thick man-made fill accumulated in this sector.

\section{SEDIMENTARY FACIES AND GEOCHEMISTRY}

Five main sedimentary facies including a total of 10 subfacies have been distinguished in the four trenches (Figs 8 and 9) according to their textural and geochemical characteristics, which essentially represent different evolutionary stages of the spring-fed lakes (Table 4). Detailed photographs taken from the walls of the trenches illustrate these facies (Figs 10 and 11).

Facies A comprise: (i) marginal rimstone subfacies A1 consisting of low porosity, massive or crudely bedded highly indurated carbonate corresponding to the annular ridge that formed the edges of the perched lake basins; (ii) colluvial subfacies A2 (Fig. 10), composed of reworked tufas derived from the erosion of subfacies A1, which consists of clast-supported breccias and poorly sorted gravels within a fine matrix; and (iii) colluvial subfacies A3 (Fig. 10) described as matrix dominated silty clay with angular reworked tufa clasts and carbonate nodules, recognized only in trenches T1 and T2 (Fig. 8) located in the older morphostratigraphic unit (Tufa 1 - Fig. 2B).

Detrital facies B consists of massive, bioturbated silty clay deposited by sheet wash in shallow littoral areas of ephemeral lakes with frequent run-off events, including abundant quartz grains (Fig. 10). The absence of a quartz source in the limited catchment area of these perched lakes supports an aeolian origin for these quartz grains.

Facies C (Figs 10 and 11) comprises carbonate sediments deposited in palustrine conditions. These include: (i) palustrine subfacies C1 consisting of massive to crudely stratified carbonates with granule-sized intraclasts and occasional secondary carbonate; (ii) subfacies C2 with the same composition as $\mathrm{C} 1$, but showing a higher degree of bioturbation and in situ plant remains (phytoherms); and (iii) subfacies C3 corresponding to buried pedogenic petrocalcic horizons mainly corresponding to carbonate silt with granule-sized intraclasts overprinted by the precipitation of massive secondary carbonate, reaching stage IV of the carbonate morphological sequence proposed by Machette (1985). This subfacies, ascribable to the development of calcretes on palustrine deposits, has been recorded in trenches T1, T2 and T3.

Organic-rich facies D was recorded in trenches T3 and T4 (Figs 9 and 11) excavated in the younger and lower morphostratigraphic unit (Tufa 3 - Fig. 2B). It consists of highly bioturbated blackish organic ooze with bioturbation voids locally filled with secondary carbonate.

Organic carbonate-rich facies E (Fig. 11), comprising four facies types, were identified in trench T3, with facies E1 also recorded in trench T4. This facies displays the most complex stratigraphy consisting of massive to banded or laminated organic-rich layers intercalated with silt-sand beds of detrital origin, often overprinted by root bioturbation. A detailed description of each facies type is presented in Table 4.

The sedimentary facies in the Marcelino palaeolake were characterized using TOC, TIC, $\mathrm{TN}$ and $C / N$ ratio. Principal component analysis (PCA, Fig. 12) of the geochemical data (Table 1) complements and reinforces the stratigraphic features shown in Table 4. The geochemical evolution of the sedimentary sequence recorded in the Marcelino palaeolake is illustrated in Fig. 13. The carbonate unit in the lower section of the sedimentary sequence (unit Ma2; Fig. 13) shows negligible TOC and TN values. Organogenic units Ma3a and Ma4b display the highest TOC and TN values (up to $4 \cdot 2 \%$ and $0.3 \%$, respectively) and the lowest TIC content ( $c a$ $5 \%)$. Banded to laminated, organic-rich units Ma3b and Ma4a show relatively high TOC values ranging from $0 \cdot 7 \%$ to $4 \cdot 7 \%$, TIC values of $c a$ $11 \%$ and the highest $C / N$ ratios recorded in the palaeolake (Fig. 13). The PCA results show that multi-element relationships are linked to the 

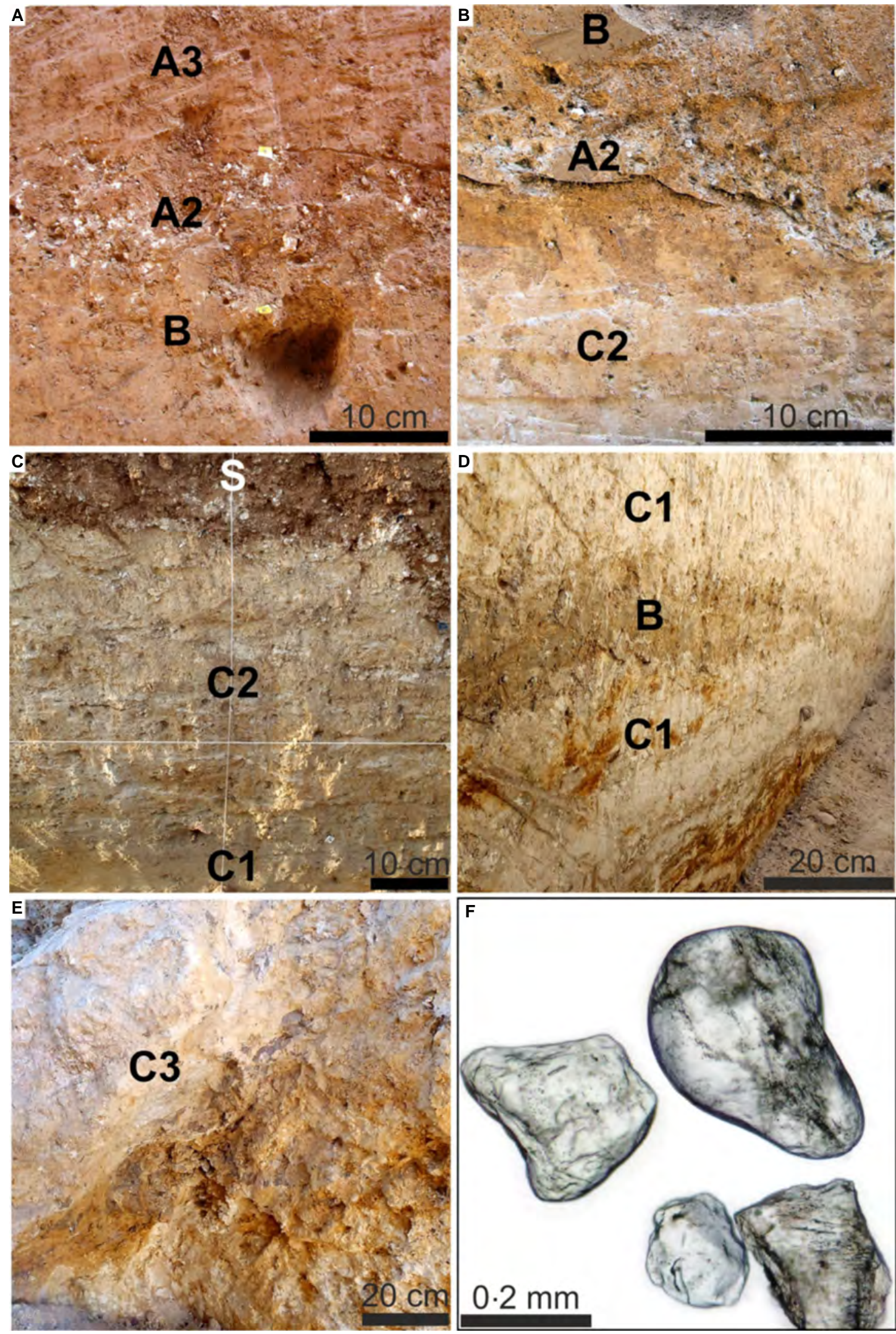

(C) 2016 The Authors. Sedimentology (C) 2016 International Association of Sedimentologists, Sedimentology, 63, 1786-1819 
main environmental conditions controlling the depositional processes in the Marcelino palaeolake. The two main eigenvectors that account for the $69.6 \%$ of the total variance (Table 1), illustrated in Fig. 12, characterize the main biogeochemical processes in the lake (carbonate production, detrital input and organic productivity). The first eigenvector (PCA1; 60.9\%) is controlled by clastic-related elements $(\mathrm{Ni}, \mathrm{Fe}$, $\mathrm{Zr}, \mathrm{Mn}, \mathrm{K}, \mathrm{Zn}, \mathrm{Mg}$, Co, K, Na, Ni, Ba, Al, As, Cd and $\mathrm{Pb}$ ) in the positive end, and TIC, $\mathrm{Ca}$ and $\mathrm{Sr}$ in the negative end. Therefore, PCA1 discriminates periods of higher clastic input to the lake (positive values, Facies B) and periods of increased endogenic carbonate precipitation (negative values, Facies E); PCA1 shows relatively high shifting values in the lower units Ma2 and Ma3a followed by a significant decrease in the upper interval of the sedimentary sequence (units Ma3b and Ma4). The element $\mathrm{Si}$ does not follow the trend of other clastic-related elements because it is largely linked to biogenic silica associated with diatom blooms in the lake. The Si/Ti ratio can be used to infer the biogenic (diatom) productivity in lacustrine systems (Melles et al., 2012); Si/Ti displays low values throughout unit Ma2 and rises in the upper units Ma3 and Ma4. The second eigenvector (PCA2), accounting for $8.7 \%$ of the total variance, is controlled by indicators related to biological activity (TOC, $\mathrm{P}$ and $\mathrm{TN}$ ) in the positive end. It discriminates periods of enhanced lake bioproductivity and eutrophication (Facies D), which are particularly high in units Ma3a and Ma4b.

\section{CHRONOLOGY}

Radiocarbon and OSL ages obtained from samples collected in trenches T1, T3 and T4 provide information on the chronology of the lacustrine and detrital infill of the basins, as well as the approximate timing of the deactivation of the springs. Geochronological data are presented graphically on composite logs constructed from partial logs recorded along the trench walls (Fig. 14). Samples collected in the Colector palaeolake (trench T1) yielded ages ranging between isotope stages MIS 3 and MIS 1 (Table 2). Organic sediments in subunit Co1c yielded a radiocarbon age of 27640 to $27192 \mathrm{yr}$ BP. Samples of silt containing quartz grains of aeolian origin from subunit Co2b of the detrital fill provided OSL ages in correct stratigraphic order of 20225 to $17605 \mathrm{yr}$ вP and 16880 to $14200 \mathrm{yr}$ BP, respectively (Table 3). The age range of the lower sample (OSL II: $20 \cdot 2$ to $17 \cdot 6$ $\mathrm{ka}$ ), collected $25 \mathrm{~cm}$ above the unconformity that records the onset of the detrital fill, could be considered as a rough approximation for the deactivation of the artesian spring and the desiccation of the lake. A charcoal sample collected in subunit Co2e $50 \mathrm{~cm}$ below the ground surface provided an age of 1174 to $979 \mathrm{yr}$ вp (Table 2).

The six radiocarbon ages obtained in Marcelino (trench T3) cover a ca $20 \mathrm{ka}$ long period between MIS 2 and the Late Holocene. Two radiocarbon dates from samples collected close to the base and top of subunit Ma2a in the lake margin yielded age ranges of 22304 to $21758 \mathrm{yr}$ BP and 13178 to $12970 \mathrm{yr}$ BP, respectively. A sample of organic sediment collected $10 \mathrm{~cm}$ below the top of subunit Ma2d was dated at 8982 to 8641 yr BP. This date can be considered as a reasonable age estimate for the soft-sediment deformation that affects unit Ma2, but not unit Ma3. Three samples of organic sediment collected in organic-rich subunits Ma3a, Ma3b and Ma5 provided consistent Holocene age estimates of 7032 to $6850 \mathrm{yr}$ вР, 4258 to $4085 \mathrm{yr}$ вР and 1812 to $1605 \mathrm{yr}$ BP, respectively (Table 2).

Two samples collected in the eastern sector of trench T4 associated with deposition in the Big

Fig. 10. (A) to (E) Detailed images of sedimentary facies recorded in trenches T1 (Colector) and T2 (Fornons) (scale bar $=10 \mathrm{~cm}$ ). (A) Trench T1, X (distance) $=49 \mathrm{~m}, \mathrm{Y}$ (altitude) $=696.5 \mathrm{~m}-$ orange clayey silt overlain by breccias and reddish silty clay. (B) Trench T1, $X=47 \mathrm{~m}, Y=695.75 \mathrm{~m}$ - thin gravel bed underlain by massive carbonate silt and overlain by clayey silt. (C) Trench T1, $X=11 \mathrm{~m}, Y=698 \mathrm{~m}$ - massive carbonate silt overlain by carbonate silt with abundant secondary carbonate pseudo-layers. (D) Trench T2, $X=6 \mathrm{~m}, Y=692 \cdot 5$ to $691 \cdot 5 \mathrm{~m}$ - grey greenish silty clay interstratified with massive pale carbonate silt. (E) Trench T2, $X=21 \mathrm{~m}, Y=693 \mathrm{~m}-$ indurated carbonate with granule-sized intraclasts. (F) Microscope photography showing subrounded to subangular quartz grains in facies B of trench T1 (sample was collected from cavity observed in photograph A) (scale bar $=0.1 \mathrm{~mm})$. The absence of quartz in the sediments recorded in the Colector watershed implies that quartz grains are allochthonous and could have only be deposited by aeolian transport. Quartz grains have an average size of $0.2 \mathrm{~mm}$ with a maximum of $0.8 \mathrm{~mm}$. 

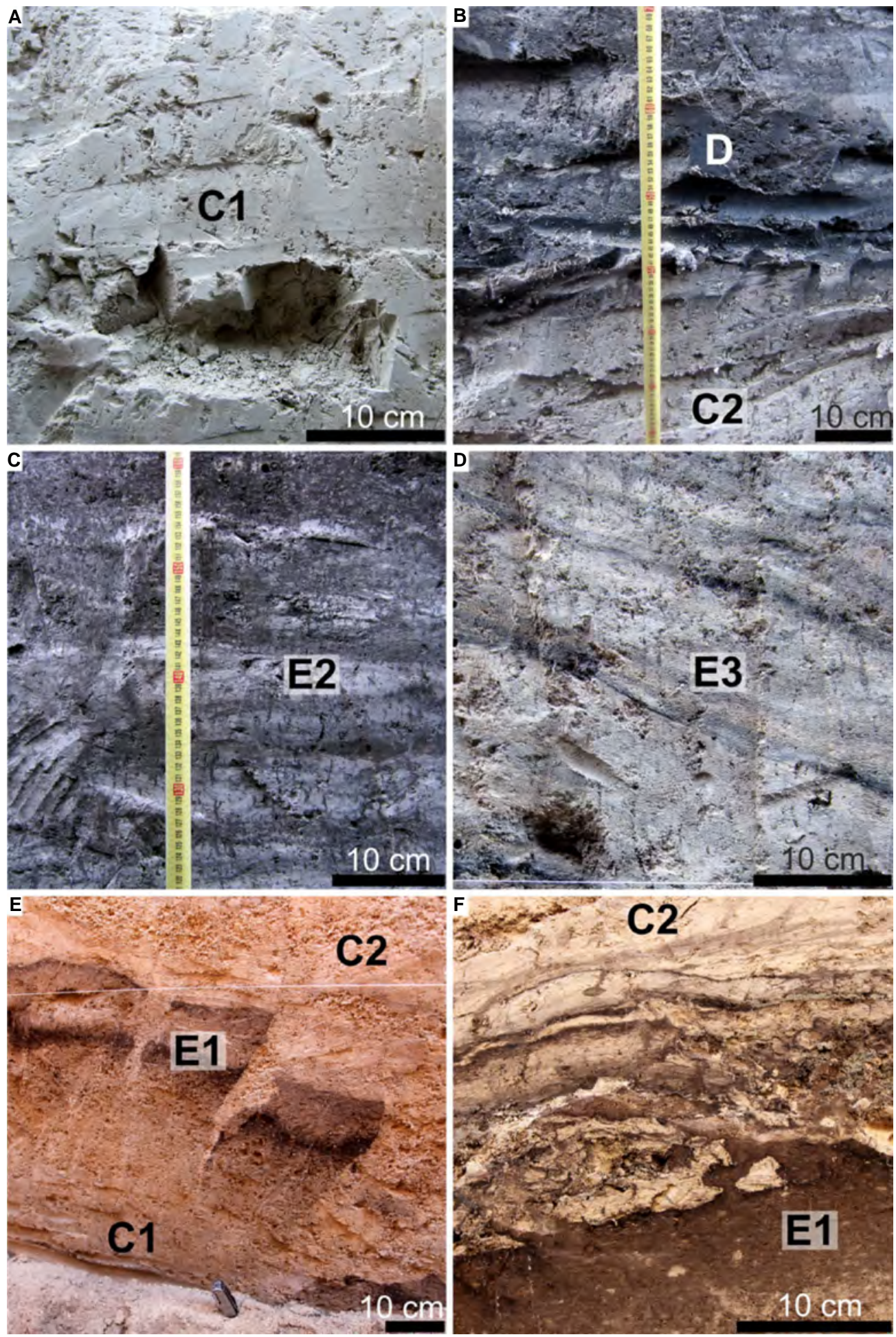

Fig. 11. Detailed images of sedimentary facies recorded in trenches T3 (Marcelino) and T4 (Basturs Lakes) (scale bar $=10 \mathrm{~cm}$ ). (A) Trench T3, $X$ (distance) $=14 \mathrm{~m}, Y$ (altitude) $=647.5 \mathrm{~m}-$ massive greenish white carbonate. (B) Trench T3, $X=48 \mathrm{~m}, Y=646 \mathrm{~m}-$ massive carbonate silt overlain by organic ooze. (C) Trench T3, $X=52 \mathrm{~m}$, $Y=646.5$ - banded pale grey and dark grey silt layers overprinted by root bioturbation. (D) Trench T3, $X=52 \mathrm{~m}$, $Y=647 \mathrm{~m}$ - banding composed of pale sandy silt and dark organic-rich layers. (E) Trench T4, $X=49 \mathrm{~m}, Y=632$ to $633 \mathrm{~m}$ - Infilled fissures recording the development of an over steepened normal fault. (F) Trench T4, $X=30 \mathrm{~m}, Y=633 \mathrm{~m}$ - Interface between banded blackish organic silt overlain by carbonate clayey silt obliterated by water-escape structures. 


\section{Carbonate precipitation}

\section{Sediment delivery}

PCA1

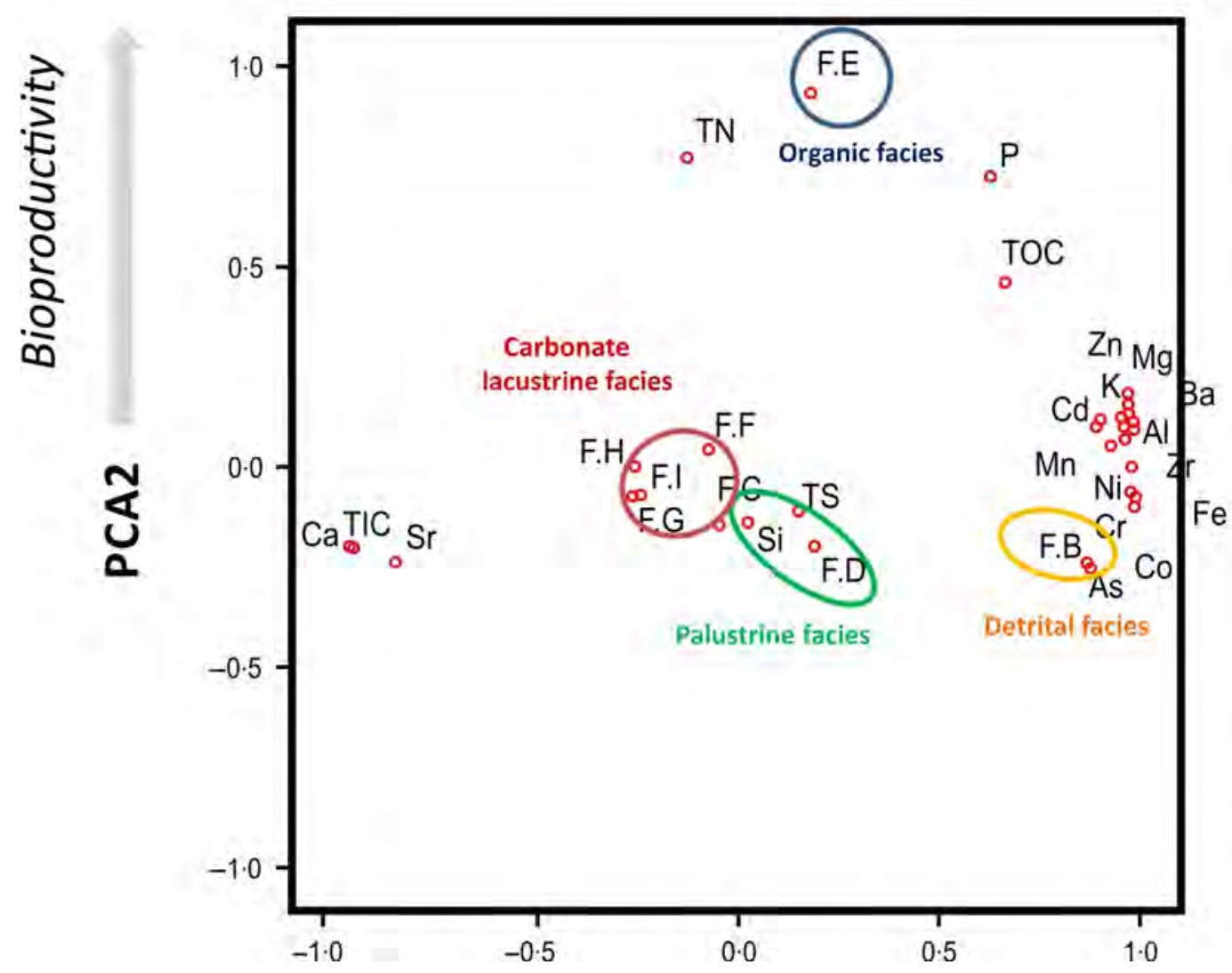

Fig. 12. Principal component analysis (PCA) of the geochemical data collected in trench T3. Negative values of PCA1 indicate an increase in carbonate precipitation, positive values reflect increasing siliciclastic sediment delivery. Higher PCA2 values are ascribable to increasing lake bioproductivity.

Lake, yielded age estimates of 24512 to 23870 yr вP and 18911 to 18551 yr вP. The latter provides a minimum age for the fault system recorded at vertical reference lines 49 to 51 (Fig. 7). Sediments in the western sector of trench T4 associated with the Small Lake were deposited during the late Holocene. Colluvial facies described in subunit Ba1c associated with rimstone erosion were deposited prior to $3511 \mathrm{yr}$ вр, as indicated by the age of sample T4C2 (3511 to 3372 yr BP; Fig. 7). A period dominated by accumulation of carbonate-rich sediments with occasional colluvial events recorded in unit Ba4 extended up to $960 \mathrm{yr}$ BP, when the system changed into a eutrophic depositional environment, as indicated by the age of organicrich sediments recorded in unit Ba5 (960 to 894 yr BP; Fig. 7).

\section{DISCUSSION}

Unlike most lacustrine systems, the lakes of the Isona tufa mound complex (ITMC) develop on prominent mounds constructed by the accumulation of calcium carbonate from artesian spring waters; they are not lakes lying at the bottom of topographic basins, but lakes surrounded by rimstones on the top of small constructional hills (Pellicer et al., 2014). Consequently, they have a very limited contributing area for surface runoff and allochthonous sediment input.

From the Neolithic onwards, most of the palaeolimnological archives in the north-eastern Iberian Peninsula are strongly influenced by human-induced alterations on lake basins (Morellón et al., 2009b; Corella et al., 2011a, 2013; Rull et al., 2011; Scussolini et al., 2011; 


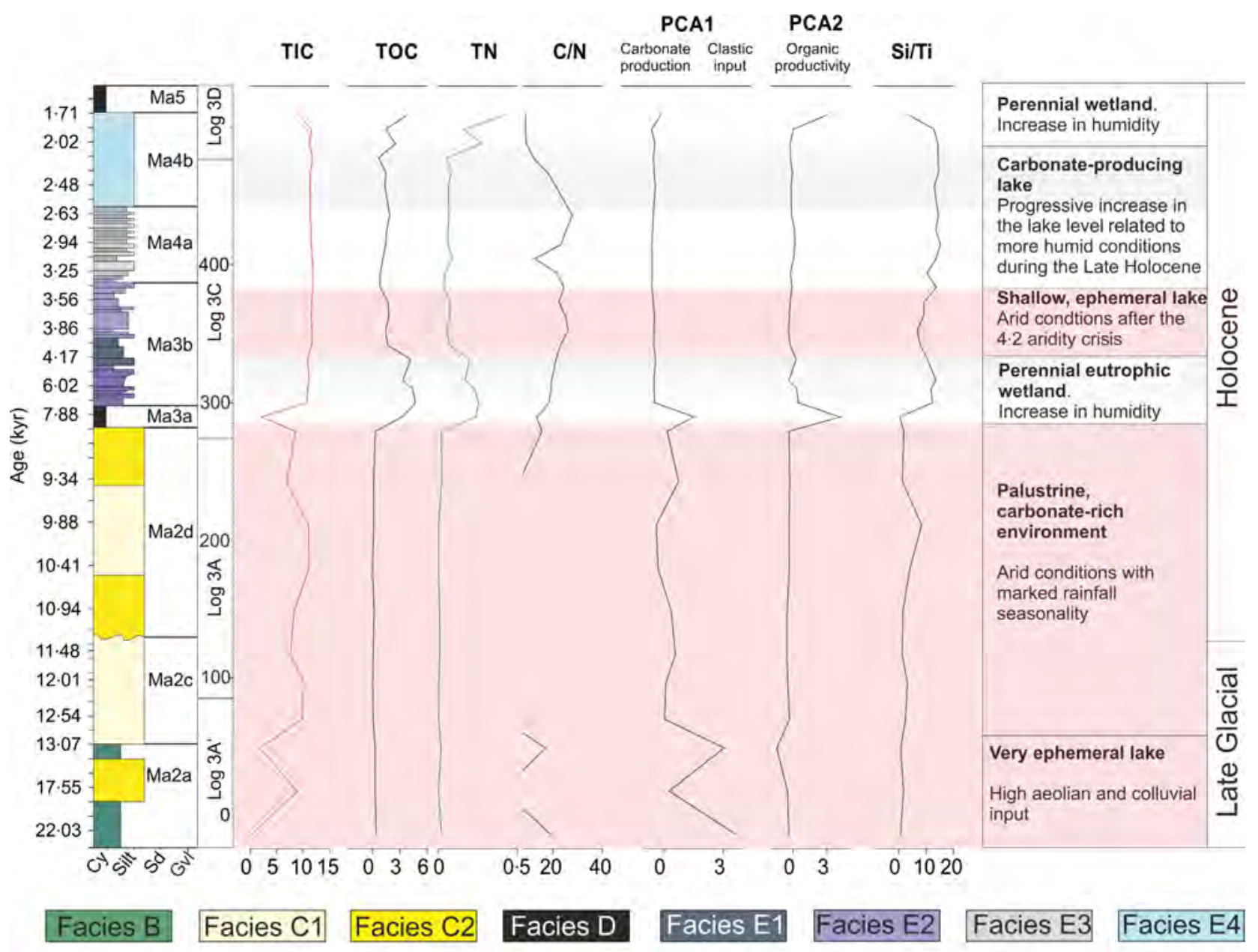

\section{Arid conditions Humid conditions}

Fig. 13. Age-depth model for the composite log of trench T3 obtained by linear interpolation of recorded radiocarbon ages and using the Analyseries software. Geochemical analyses results from 31 samples collected along the trench are illustrated by diagrams showing Total Inorganic Carbon (TIC), Total Organic Carbon (TOC), Total Nitrogen $(\mathrm{TN})$ and Carbon to Nitrogen ratio $(C / N)$, Principal Component Analyses (PCA1 and PCA2) and Silicon to Titanium ratio $(\mathrm{Si} / \mathrm{Ti})$.

Revelles et al., 2015). Understanding the contribution of anthropogenic and climatic factors affecting the sediment dynamics in lacustrine sequences is often a complicated task (Corella et al., 2012; Barreiro-Lostres et al., 2015). However, anthropogenic influence in the depositional evolution of the ITMC palaeolakes is likely to be negligible, due to their exiguous catchment area. For that reason, palaeolimnological changes inferred from these lacustrine basins are probably related to the palaeohydrological evolution of the system and palaeoclimatic variability.

An additional innovative aspect of the work presented here is the investigation via trenching of the lake sediments, a technique rarely used for the characterization of recent lake sediments. The trenching technique is mostly used in palaeoseismological investigations (McCalpin, 2009, 2013), but has also been applied satisfactorily to the study of lacustrine environments (e.g. King, 1994; Briggs et al., 2005; Reheis \& Miller, 2010; Gutiérrez et al., 2013). Trenching surveys presented in the present work permitted a detailed characterization of the lateral and vertical variations of the deposits filling the late Pleistocene palaeolakes associated with different tufa mounds, aiding the inference of evolving palaeoenvironmental and palaeohydrological conditions of the ITMC. 


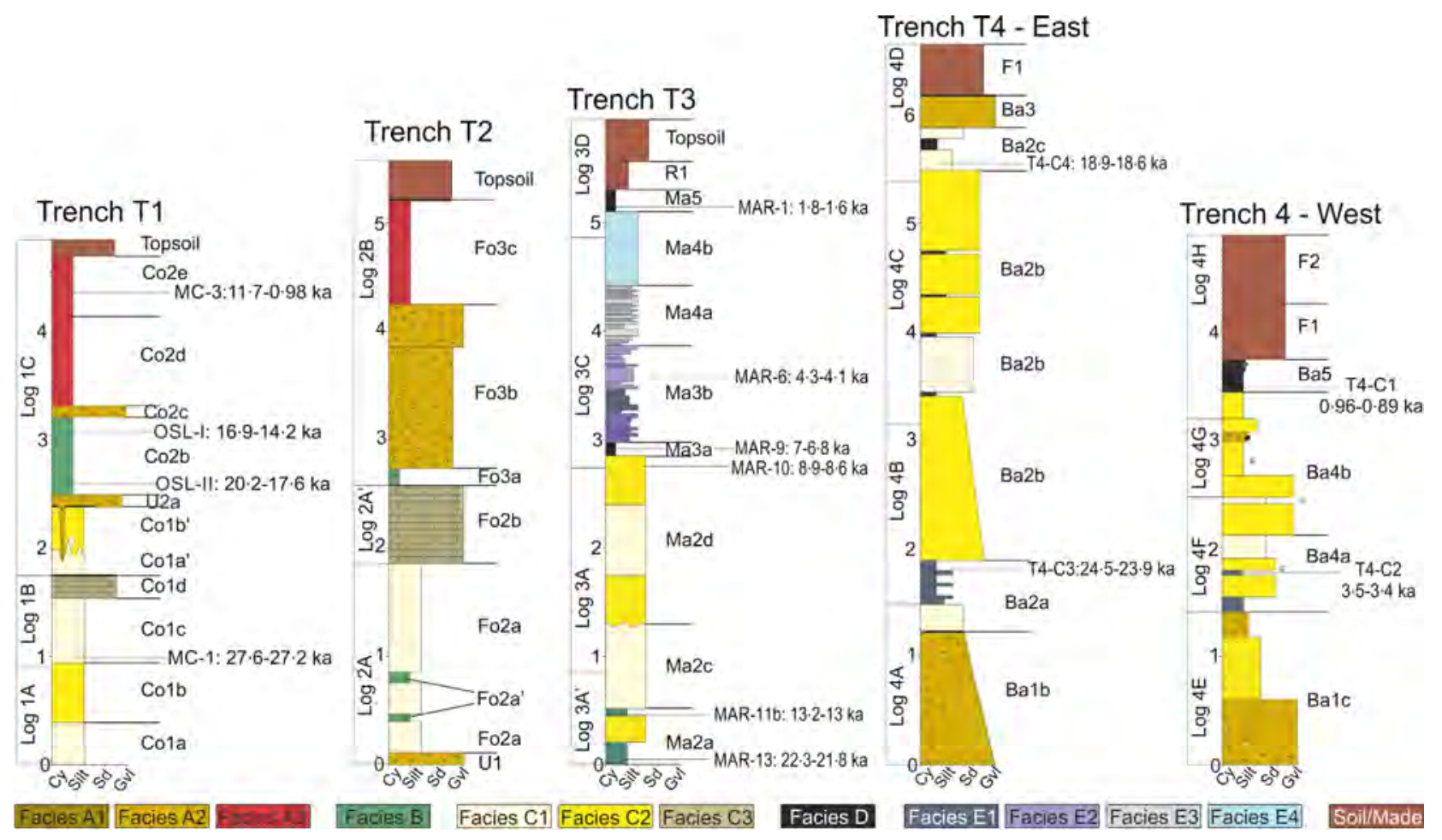

Fig. 14. Diagram illustrating composite logs constructed from partial logs recorded in each trench illustrating facies types (colour coded), position of calibrated ages presented in Table 2 and stratigraphic units described in Figs 4 to 7. The position of the partial logs used is presented in Figs 8 and 9. Facies types are described in detail in Table 4.

Five main sedimentary facies characterized by distinctive textural and geochemical features have been differentiated, representing the depositional environments of the spring-fed lakes (Table 4). Rimstone facies formed by calcium carbonate precipitation during episodes of lake water over-spilling along the outer margins of the lakes (Pedley, 2009). Carbonate-rich palustrine facies, corresponding to late Pleistocene sediments deposited in the shallow water environments that dominate the littoral regions of the Fornons and Colector palaeolakes. Carbonate-rich sediments could only be deposited in association with an active feeding spring. The latter are unconformably overlain towards the lake centre by late Pleistocene-Holocene colluvial facies, consisting of massive reddish finegrained and gravelly deposits. These represent the infill of the depression by detrital facies reworked from the restricted margins of the lake basin following the deactivation of the spring and the desiccation of the lake. In the lower elevation Basturs and Marcelino lakes, carbonaterich palustrine facies are interstratified or overlain by organic-rich beds indicative of water level fluctuations associated with palaeohydrological and/or palaeoclimatic variations. These facies represent transitional conditions between lacustrine and terrestrial environments and record significant periods of subaerial exposure and pedogenesis (AlonsoZarza \& Wright, 2010). Similar facies associations have been described in several lake records in the Iberian Peninsula (Valero-Garcés et al., 2014), reflecting rapid fluctuations of the lake level and water table, probably related to changes in the seasonal precipitation patterns. The green to red clay-rich facies B are mainly sheet wash deposits derived from the erosion of soils with decalcified clays developed on the marginal tufa deposits. The mineralogy of these sediments, including quartz grains, also indicates some aeolian input.

Deposition rates of carbonate facies range from 0.5 to $0.7 \mathrm{~mm} \mathrm{yr}^{-1}$, contrasting with the sedimentation rates of $c a 0.05 \mathrm{~mm} \mathrm{yr}^{-1}$ calculated for the detrital facies B in trench T3. Moreover, organic-rich facies show sedimentation rates of 0.1 to $0.25 \mathrm{~mm} \mathrm{yr}^{-1}$. Similar carbonate and organic sedimentation rates in littoral environments have been estimated in karstic lakes in the Iberian Peninsula (Lake Estanya - Morellón 
et al., 2009b; Lake Montcortès - Corella et al., 2011a; Lake Arreo - Corella et al., 2013). The colluvial facies that fill the depressions left behind after the desiccation of the Colector and Fornons lakes show deposition rates of $c a$ $0 \cdot 1 \mathrm{~mm} \mathrm{yr}^{-1}$.

The deposits of the investigated lakes show common structural characteristics. The lake sediments display a general inward dip, increasing towards the lake centre, and an offlap arrangement. The dip of the strata also shows a progressive upward attenuation, forming cumulative wedge outs. These features record: (i) differential synsedimentary subsidence in the lake basins, more pronounced in the central sector where sedimentary units typically attain higher thickness; and (ii) progressive contraction of the sedimentation zone and the expansion of an external aureole underlain by lake sediments acting as the source for reworked deposits.

Differential subsidence in the lake bottom may be related to progressive loss of basal support induced by internal erosion and dissolution by groundwater flows rising through the clay-rich and gypsum-bearing Garumn Facies (Rosell et al.,
2001). The higher subsidence in the central sector may control the shrinkage of the sedimentation zone as recorded by the offlap arrangement. The latter geometrical feature determines that the aggregate thickness of the sediments exposed in the trenches is substantially higher than their depth (for example, trench T3). Trenches T2, T3 and T4 also show synformal structures affecting the marginal lake deposits. Subunit Fo2a in trench T2, composed of carbonate interstratified with two thin detrital beds was deposited in the nearshore sector and is affected by passive folding (Fig. 5). Subunit Ma2a in trench T3 is affected by a marginal synform between vertical reference lines 6 and 34 (Fig. 6). The attenuation of the folding structure in unit Ma2c, together with its lateral thickness changes suggest that sagging occurred during deposition of that unit. This local structure may correspond to a drape fold on unconsolidated sediments related to a buried graben structure. Sagging structures involve lateral contraction, which is commonly counterbalanced through layer-parallel lengthening and the development of marginal extensional structures (e.g. Gutiérrez et al., 2012b).
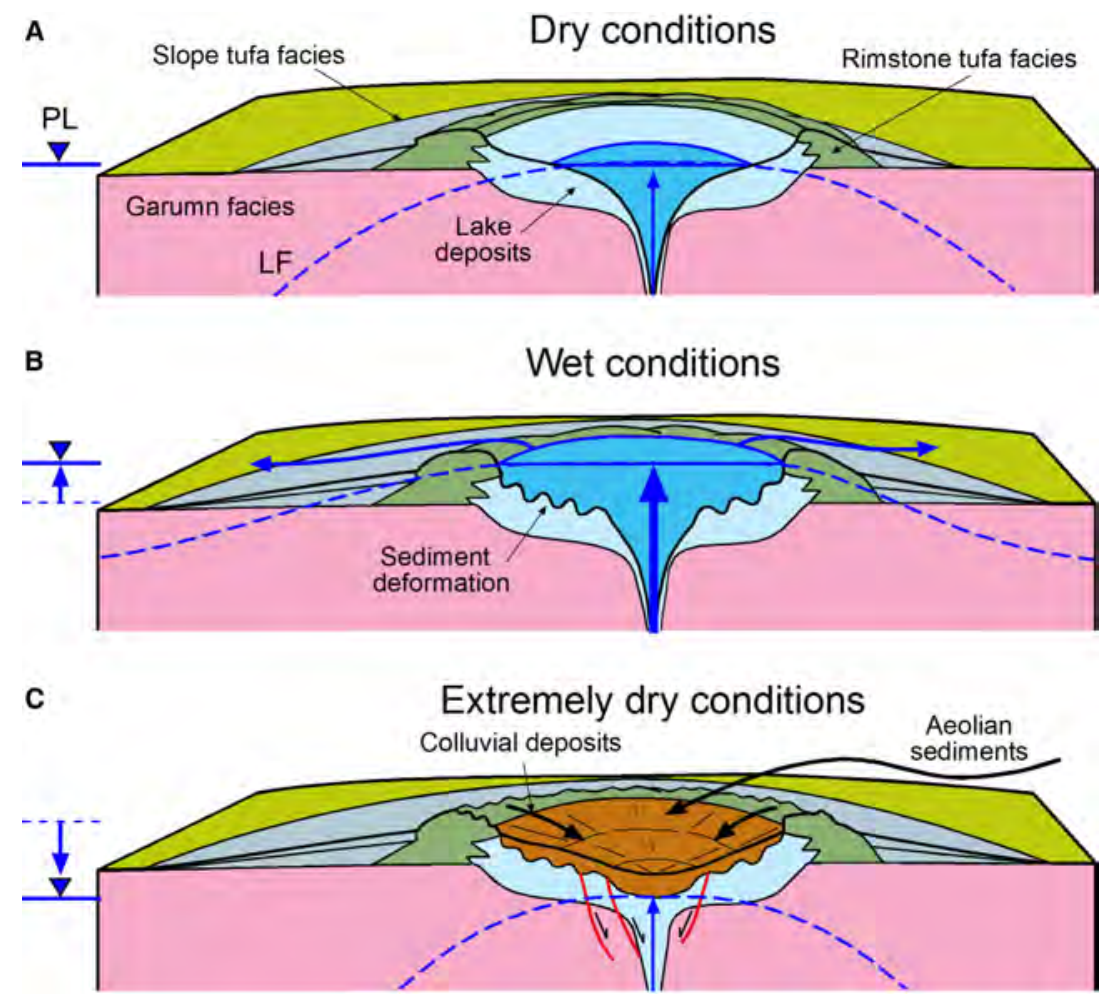

Fig. 15. Evolutionary model of tufa mound formation. Relatively dry conditions followed by wet conditions caused rapid aquifer recharge and high hydrostatic pressure prompting lacustrine sediment deformation and opening of lower level groundwater outlets. Extremely dry conditions favoured lowering of the water table leaving a depression gradually filled with allocthonous aeolian deposits and colluvium produced from cannibalization of the surrounding rimstones: LF, local flow; PL, potentiometric level. 
Soft-sediment deformation structures, including metre-scale convolute beds and centimetre to decimetre-scale flames, dykes and fluidescape structures are common in the finegrained lake deposits of the studied basins. These penecontemporaneous structures record pore fluid overpressure conditions that involve reductions in the normal effective stress and shear strength of the sediments. Although liquefaction structures are commonly related to earthquake-induced shaking, in the particular case herein they can be also explained by increases in the hydraulic head of the artesian hydrogeological system (Collinson, 1994; Obermaier, 2009).

Trenches T1 and T2 excavated in old palaeolakes reveal the stratigraphic signature of the deactivation of the artesian springs and the change from lacustrine to detrital deposition in the desiccated depressions. This major palaeohydrological event is recorded by detrital sediments lying on erosional unconformities cutacross the lake deposits. In trench $\mathrm{T} 1$, the unconformity is accompanied by downward tapering fissures filled by detrital sediments and cross-cutting soft-sediment deformation in lake deposits. This change in the rheology of the lake deposits and the development of fissures is probably related to the dewatering of the lake sediments associated with interruption of the groundwater discharge and the consequent differential contraction and consolidation processes. At the present time, fissures and scarplets commonly occur during periods of low water level in the margins of the Basturs Small Lake.

The Colector and Fornons palaeolakes, located on the top of the morphostratigraphic unit Tufa 1 (Fig. 2), consist of small enclosed depressions developed in the centre of large tufa mounds (Pellicer et al., 2014). These landforms fall within the category of 'regular with lake mounds' of the Scheuer \& Schweitzer (1985) classification scheme. Each of these perched lake basins has a catchment area smaller than $0.04 \mathrm{~km}^{2}$. The infill of these palaeolake depressions consists of palustrine facies $\mathrm{C}$ (and detrital facies $B$ in T2) in the littoral region, overlain towards the lake centre by colluvial facies A. These facies record two contrasting depositional environments: (i) an earlier one associated with the growth of a tufa mound with deposition of palustrine facies $C$ in the lacustrine basin; (ii) a second one, filling the desiccated lake depression, dominated by colluvial facies A related to the erosion of the spatially restricted basin margins and the supply of aeolian dust including allochthonous quartz (i.e. there is no quartz source in the surface catchment area of the lakes). The unconformable offlap contact between the lake deposits and the overlying detrital fill (Figs 5 and 6) records the deactivation of the spring and the desiccation of the lake. The deactivation of the springs feeding the Colector and Fornons lakes is probably related to a period of arid climatic conditions, which caused a drop of the piezometric level following the last major ice advance recorded in the Pyrenees between $22 \mathrm{ka}$ and $18 \mathrm{ka}$ (García-Ruiz et al., 2003; González-Sampériz et al., 2006).

Five units exposed along trench $\mathrm{T} 3$ in the Marcelino Lake show a general dip towards the centre of the depression with the oldest units consisting of facies B located in the marginal sector. An age-depth model for the composite log of trench T3 illustrates the main geochemical signatures of facies recorded in this trench (Fig. 13). Detrital facies B, dated at ca $22 \mathrm{ka}$ and 13 ka show very low total carbon (TC) and a high content of detrital elements not related to carbonates derived from rimstones at the lake margin (PCA1; Fig. 13), probably indicative of aeolian sediment input. The development of an ephemeral lake and deposition of palustrine-carbonate-rich facies $\mathrm{C}$ (unit Ma2) overlying unit Ma1 occurred some time during the time span covering the last stage of the Late Glacial and the early Holocene. The low $\mathrm{Si} / \mathrm{Ti}$ values recorded during deposition of unit Ma2 (Fig. 13) suggest a near absence of diatoms, indicating that lacustrine conditions were uncommon and/ or alkaline conditions promoted the dissolution of the diatom frustules.

The change to organic-rich deposition (Unit Ma3) recorded in Marcelino Lake at ca $8.5 \mathrm{ka}$ (radiocarbon date T3-MAR10; Fig. 6) suggests a large increase in the effective moisture. This is in agreement with a delayed onset of humid conditions during the early Holocene inferred from several records in the Mediterranean region (Pèrez-Obiol \& Julià, 1994; Morellón et al., 2009b; Pérez-Sanz et al., 2013; Vegas-Vilarrúbia et al., 2013), in contrast to wet conditions starting at an earlier stage in Atlantic regions of the Iberian Peninsula (e.g. Moreno et al., 2010). This positive hydrological balance in lake systems has been tentatively related to an increase in the frequency and magnitude of precipitation and run-off events (Morellón et al., 2009b). 
The onset of organic lacustrine facies $\mathrm{D}$, the increase in $\mathrm{Si} / \mathrm{Ti}$ ratio and TOC and the low $C / N$ (unit Ma3) indicate a rise of the lake level and the development of an organic-rich lacustrine system from $\mathrm{ca} 8.5$ to $4.2 \mathrm{ka}$ with increasing bioproductivity, high anoxic conditions and a more acidic hypolimnion with the consequent dissolution of calcite precipitating in the epilimnion of the lake as described in other similar Pyrenean lacustrine systems (Corella et al., 2011b, 2013). The low $C / N$ ratio also indicates a higher content of aquatic organic matter during this interval (Meyers, 2003). The development of palustrine facies E2 at $c a 4.2 \mathrm{ka}$, with abundant hints of bioturbation and higher $C / N$ ratio reflects low lake levels and the establishment of an ephemeral lake within 4.2 to $1.7 \mathrm{ka}$ вP (Fig. 13). This hydrological shift towards more arid conditions seems to be coeval with the $4.2 \mathrm{ka}$ aridity crisis documented in Europe and the Mediterranean area (Drysdale et al., 2006; Jalut et al., 2009), and records a major global climatic event that occurred between $4200 \mathrm{yr}$ and $3800 \mathrm{yr}$ вр (Mayewski et al., 2004). Rising humidity at $c a 1.7 \mathrm{ka}$ (Ma5) indicated by the increase in TOC, lower $C / N$ ratios and the presence of organic-rich facies D (Fig. 13) also reflects a regional signal comparable to other palaeoenvironmental records in north-eastern Spain, showing more humid conditions for the last two millennia (e.g. González-Sampériz et al., 2008; Morellón et al., 2008; Corella et al., 2013).

Trench T4 in the Basturs Lakes exposed sediments corresponding to two adjacent basins separated by a buried rimstone. Sediments to the east of the rimstone associated with the Big Lake are late Pleistocene in age (24.5 to $18.5 \mathrm{ka})$, whereas sediments associated with the Small Lake to the west were deposited during the late Holocene ( 3.5 to $0.8 \mathrm{ka})$. The unconformable contact at the base of unit Ba2 (Fig. 7) corresponds to the boundary between rimstone facies and Upper Pleistocene lake sediments associated with the Big Lake. These sediments were deposited simultaneously with lacustrine sediments in the Colector, Fornons and Marcelino lakes located at higher altitudes. The Small Lake formed some time in the Holocene at a lower elevation than the adjacent Big Lake. The deposits of this lake onlap unconformably the rimstone and the associated colluvial facies (contact between units Ba1 and Ba4) and contain abundant reworked tufa clasts derived from the adjacent rimstone (Fig. 7). Layers with iron oxides indicate episodes of regression of the Small Lake water body, whereas organic-rich fine sediments with bioturbation are interpreted as relatively high stands.

Unexpectedly, the available geochronological data indicate that lacustrine deposition occurred simultaneously at $\mathrm{ca} 22 \mathrm{ka}$ in palaeolakes situated at three different elevations: Colector 700 m; Marcelino - 650 m; and Basturs Big Lake - $635 \mathrm{~m}$. Therefore, the deactivation of the upper lakes cannot be explained by the opening of the Marcelino and Basturs lakes. Subsequently, the drop in the piezometric level of the Areny-Montsec aquifer and the final deactivation of the upper lakes could be associated with the opening of lower altitude springs (Fig. 2) combined with generally drier climate conditions. On the other hand, the spatial distribution of the tufa units (Fig. 2) and the available chronological data for the Isona tufa mound complex (ITMC; Pellicer et al., 2014) illustrate an overall northward migration of the springs towards the drainage acting as the main local base level (Abella River). Moreover, the easternmost palaeolakes and the largest Basturs Lake show a clear N10E alignment. These features suggest that the position of the springs is controlled by the entrenchment of the drainage network, which causes a progressive reduction in the thickness of the confining unit (Garumn Facies) and fractures that function as preferential pathways for groundwater discharge.

The evolutionary model illustrated in Fig. 15 shows three main stages of tufa mound formation and deactivation. Seasonal weather variations consisting of humid winters and generally drier summer conditions during the last glacial maximum (LGM) have recently been proposed in the Western Mediterranean (Beghin et al., 2015). The seasonal changes in precipitation may have prompted drops in the aquifer piezometric level during the summer months, followed by rises after the winter season (Fig. 15A and B). At the present time, the water level in the lakes shows rapid responses (within weeks) to rainfall. The onset of new groundwater outlets in the ITMC could be related to episodes of sustained wet periods with a high hydraulic head in the aquifer. Soft-sediment deformation at the interface between $\mathrm{Co}^{\prime}$ and Co2 in the Colector palaeolake (Fig. 4) is probably related to increases in the piezometric level during this period. Subsequent relatively drier weather conditions during the Oldest Dryas and/or the opening of new lower altitude groundwater outlets 
may have caused a sustained drop of the piezometric level, favouring desiccation of the lakes. The depressions left behind by the deactivation of the upper tufa mound groundwater outlets (Colector and Fornons) were gradually filled by colluvium derived from the erosion of the rimstones surrounding the depression including fine-grained aeolian particles (Fig. 15C), at least up to 1174 to 979 yr вP (Table 2).

The U/Th dates collected from slope and rimstone facies associated with the Colector and Fornons palaeolakes (Linares et al., 2010a,b; Pellicer et al., 2014) suggest that the main constructional phase of the morphostratigraphic unit Tufa 1 (Fig. 2) is older than 350 ka. Furthermore, tufas associated with the Marcelino and Basturs lakes indicate a minimum age for these lower altitude groundwater outlets of $107 \mathrm{ka}$ and $106 \mathrm{ka}$, respectively (Linares et al., 2010a). However, stratigraphic and geochronological data from trench $\mathrm{T} 1$ indicate that the Colector depression was an active spring-fed lake until some time between $27.6 \mathrm{ka}$ and $20.2 \mathrm{ka}$ (Table 2) and that the Marcelino and Basturs Lakes are still active groundwater outlets.

The excavation of trenches in dry lakes and lacustrine terraces offer a number of advantages with respect to boreholes:

1 Trenches provide long artificial exposures at key sites adapted to the characteristics of the sedimentary environment and the aims of the investigation. Most of the trenches excavated in this work, as long as $74 \mathrm{~m}$, extended from the edge to the centre of the lake depressions.

2 Trenching methods allow a precise analysis of the geometrical characteristics of the sedimentary units, the relationship between these units and lateral facies changes. This feature is nicely illustrated by trench T4 (Fig. 7), which unexpectedly exposed sediments corresponding to two different lakes separated by a concealed rimstone. The excavation of various trenches with different orientations provides insight into the three-dimensional architectural characteristics of the sediments.

3 Trenches allow unambiguous identification of major discontinuities, stratigraphic arrangements and deformation structures, commonly overlooked with borehole records. This is illustrated by the unconformities that record the deactivation of the lakes in trenches $\mathrm{T} 1$ and $\mathrm{T} 2$, the general offlap arrangement of the lacustrine deposits related to the progressive contraction of the lakes, or the various brittle and ductile non- tectonic deformation structures observed in all of the trenches.

4 Trenches offer greater probabilities for collecting high quality, undisturbed samples for dating (e.g. Gutiérrez et al., 2013) and calculating sedimentation rates in different environments within the lacustrine basins. For instance, significant lateral thickness variations of specific units in trench T3 determine considerably different aggradation rates across the lake for the same periods.

5 Trenches may also help in identifying subaqueous mass movements and reworked sediments, which are common in lake basins but difficult to recognize from borehole logs (e.g. Gutierrez et al., 2012a).

Some of the main limitations of the trenching technique in the study of lake sediments include: (i) impracticability in flooded areas; (ii) restricted depth of the excavations; (iii) low relative spatial coverage in large lakes; (iv) probable difficulties related to the presence of hard sediments as illustrated by indurated tufas recorded in trenches T1 (Fig. 4) and T4 (Fig. 7); (v) potential safety problems; and (vi) permit constraints.

\section{CONCLUSIONS}

This work makes use of trenching methods to analyse late Quaternary sediments deposited in palaeolakes and active lakes associated with unique tufa mounds in the Pyrenees, which constitute the morphostratigraphic record of springs related to a confined artesian aquifer. To the knowledge of the present authors, these are the only non-thermal tufa mounds documented in Europe, and this is the first time that the infill of such peculiar lake systems has been investigated from a sedimentological perspective. The main outcomes of this work include:

1 Recent lacustrine sediments are often studied using borehole records. This work illustrates that trenches, despite their limited depth of investigation, have several advantages with respect to boreholes and may be used satisfactorily as a complementary method. Trenches provide artificial exposures adapted to the characteristics of the sedimentary environment that allow a more precise analysis of the geometrical characteristics and relationships of the sedimentary units. Furthermore, trenches permit the identification of features often overlooked with borehole records (for example, major 
discontinuities, deformation structures and palaeolandslides), and provide highly favourable conditions for collecting adequate samples for dating and calculating sedimentation rates. Trenching can also help in the identification of sediments reworked from the lake shores, which are common in lacustrine basins but difficult to recognize from borehole logs alone.

2 The lakes developed within the tufa mounds display facies associations and deposition rates similar to those recorded in other karstic lakes in the Iberian Peninsula. On the other hand, the deposits of the four investigated lakes show common structural characteristics consisting of a general inward dip, increasing towards the lake centre, and an offlap arrangement. Softsediment deformation structures commonly recorded in the fine-grained lake deposits can be ascribed to increases in the hydraulic head of the artesian aquifer associated with major recharge episodes, although seismic loading cannot be ruled out as a potential trigger.

3 Facies associations described in the older palaeolakes located on the upper morphostratigraphic unit illustrate the sharp change from lacustrine to detrital deposition, indicative of the deactivation of the artesian springs associated with these tufa mounds. Chronological data from the Colector palaeolake suggest that the deactivation of these upper lakes occurred some time between $27 \mathrm{ka}$ and $18 \mathrm{ka}$. A period of arid climatic conditions recorded in the Pyrenees following the last major ice advance, which probably caused a sustained drop of the piezometric level, may have contributed to the final deactivation of the system.

4 Geochemical analyses of the sediments recorded in the Marcelino Lake coupled with geochronological data provide a continuous palaeoclimatic record of the last $22 \mathrm{ka}$. The change from palustrine deposition to the accumulation of organic-rich sediments at $c a 8.5 \mathrm{ka}$ marks the onset of wetter climate conditions, coinciding with the pattern recorded in other areas of the Mediterranean sector and contrasting with the earlier onset of wetter weather conditions recorded in lacustrine deposits studied in the Atlantic regions of the Iberian Peninsula.

5 Geochronological data available from three lakes located at elevations ranging between $700 \mathrm{~m}$ and $635 \mathrm{~m}$ indicate that these were active simultaneously. Therefore, the deactivation of the upper lakes cannot be explained by the onset of the lower altitude lakes alone. A number of artesian springs recorded along the
Basturs and Conques River tributaries (Fig. 2; Linares, 1995) may have contributed significantly to the final deactivation of the upper lakes. Future research focused on the dating of tufas associated with these lower level springs may provide new insight into the overall hydrogeological evolution of the system. Furthermore, as the available U/Th datings indicate (Linares et al., 2010a,b), the Basturs and Marcelino tufa mounds located at the lower morphostratigraphic unit and the Colector and Fornons palaeolakes situated at the upper unit (Fig. 2), have been active for over $100 \mathrm{ka}$ and $350 \mathrm{ka}$, respectively. This large temporal lag suggests that these lakes had a prolonged residual activity and that their basins may host exceptionally long lacustrine records with great potential for future palaeoenvironmental investigations.

\section{ACKNOWLEDGEMENTS}

We thank the Isona i Conca Dellà Council for sponsoring trenching in the Colector palaeolake and providing accommodation during part of the fieldwork, and Josep Maria Marc Olives, Josep Maria Fite, Jaume Abella and Maria Teresa Hom for granting permission for excavation on their properties. We also thank Veronica Rodrígues and Angel Arantegui for assistance during fieldwork, Rosa Ensenyat for providing logistical support and the IPE-CSIC laboratory services for their support in the geochemical analyses. We also thank the reviewers Rudy Swennen and an anonymous, the editors Tracy Frank and John Reijmer, and Michael Sheehy from the Geological Survey of Ireland for their valuable comments and suggestions, which have greatly improved the original manuscript. The work has been partially financed by project CGL2013-40867-P (Ministerio de Economía y Competitividad, Spain).

\section{REFERENCES}

Alonso-Zarza, A.M. and Wright, V.P. (2010) Palustrine carbonates. In: Carbonates in Continental Settings: Processes, Facies, and Application, Developments in Sedimentology (Eds A.M. Alonso-Zarza and L.H. Tanner), pp. 103-131. Elsevier, Amsterdam, The Netherlands.

Altunel, E. and Hancock, P.L. (1993) Morphology and structural setting of Quaternary travertine of Pamukkale, Turkey. Geol. J., 28, 335-346.

Ardèvol, Ll, Klimowitz, J., Malagón, J. and Nagtegaal, P.J.C. (2000) Depositional sequence response to foreland 
deformation in the Upper Cretaceous of the Southern Pyrenees, Spain. Am. Assoc. Pet. Geol. Bull., 84, 566-587.

Barnolas, A. and Pujalte, V. (2004) La Cordillera Pirenaica. Definición, límites y división. In: Geología de España (Ed. J.A. Vera), pp. 233-241. Sociedad Geologica de España IGME, Madrid, Spain.

Barreiro-Lostres, F., Brown, E., Moreno, A., Morellón, M., Abbott, M., Hillman, A., Giralt, S. and Valero-Garcés, B. (2015) Sediment delivery and lake dynamics in a Mediterranean mountain watershed: human-climate interactions during the last millennium (El Tobar Lake record, Iberian Range, Spain). Sci. Total Environ., 533, 506519.

Beghin, P., Charbit, S., Kageyama, M., Combourieu-Nebout, N., Hatté, C., Dumas, C. and Peterschmitt, J.Y. (2015) What drives LGM precipitation over the western Mediterranean? A study focused on the Iberian Peninsula and northern Morocco. Climate Dynam., 46, 2611-2631.

Benson, L.V. (2004) The tufas of Pyramid Lake. U.S. Geological Survey Circular 1267, Nevada, 14 pp.

Benson, L., Kashgarian, M. and Rubin, M. (1995) Carbonate deposition, Pyramid Lake subbasin, Nevada: 2. Lake levels and polar jet stream positions reconstructed from radiocarbon ages and elevations of carbonates (tufas) deposited in the Lahontan basin. Palaeogeogr. Palaeoclimatol. Palaeoecol., 117, 1-30.

Briggs, R.W., Wesnousky, S.G. and Adams, K.D. (2005) Late Pleistocene and late Holocene lake highstands in the Pyramid Lake subbasin of Lake Lahontan, Nevada, USA. Quatern. Res., 64, 257-263.

Claes, H., Soete, J., Van Noten, K., El Desouky, H., Erthal, M.M., Vanhaecke, F., Ozkul, M. and Swennen, R. (2015) Sedimentology, three-dimensional geobody reconstruction and carbon dioxide origin of Pleistocene travertine deposits in the Ballık area (south-west Turkey). Sedimentology, 62, 1408-1445.

Collinson, J. (1994) Sedimentary deformational structures. In: The Geological Deformation of Sediments (Ed. A. Maltman), pp. 95-125. Chapman and Hall, London.

Corella, J.P., Moreno, A., Morellón, M., Rull, V., Giralt, S., Rico, M., Pérez-Sanz, A. and Valero-Garcés, B.L. (2011a) Climate and human impact on a meromictic lake during the last 6,000 years (Montcortès Lake, Central Pyrenees, Spain). J. Paleolimnol., 46, 351-367.

Corella, J.P., Amrani, A., Sigró, J., Morellón, M., Rico, E. and Valero-Garcés, B. (2011b) Recent evolution of Lake Arreo, northern Spain: influences of land use change and climate. J. Paleolimnol., 46, 469-485.

Corella, J.P., Brauer, A., Mangili, C., Rull, V., VegasVilarrúbia, T., Morellón, M. and Valero-Garcés, B.L. (2012) The 1.5-ka varved record of Lake Montcortès (southern Pyrenees, NE Spain). Quatern. Res., 78, 323-332.

Corella, J.P., Stefanova, V., El Anjoumi, A., Rico, E., Giralt, S., Moreno, A., Plata-Montero, A. and Valero-Garcés, B.L. (2013) A 2500-year multi-proxy reconstruction of climate change and human activities in northern Spain: the Lake Arreo record. Palaeogeogr. Palaeoclimatol. Palaeoecol., 386, 555-568.

Drysdale, R., Zanchetta, G., Hellstrom, J., Maas, R., Fallick, A., Pickett, M., Cartwright, I. and Piccini, L. (2006) Late Holocene drought responsible for the collapse of Old World civilizations is recorded in an Italian cave flowstone. Geology, 34, 101-104.
Ford, T.D. and Pedley, H.M. (1996) A review of tufa and travertine deposits of the world. Earth-Sci. Rev., 41, 117-175.

Galbraith, R.F. and Roberts, R.G. (2012) Statistical aspects of equivalent dose and error calculation and display in OSL dating: an overview and some recommendations. Quat. Geochronol., 11, 1-27.

García-Ruiz, J.M., Valero-Garcés, B.L., Martí-Bono, C. and González-Sampériz, P. (2003) Asynchroneity of maximum glacier advances in the central Spanish Pyrenees. J. Quatern. Sci., 18, 61-72.

González-Sampériz, P., Valero-Garcés, B.L., Moreno, A., Jalut, G., García-Ruiz, J.M., Martí-Bono, C., DelgadoHuertas, A., Navas, A., Otto, T. and Dedoubat, J.J. (2006) Climate variability in the Spanish Pyrenees during the last 30,000 yr revealed by the El Portalet sequence. Quatern. Res., 66, 38-52.

González-Sampériz, P., Valero-Garcés, B.L., Moreno, A., Morellon, M., Navas, A., Machin, J. and Delgado-Huertas, A. (2008) Vegetation changes and hydrological fluctuations in the Central Ebro Basin (NE Spain) since the Late Glacial period: saline lake records. Palaeogeogr. Palaeoclimatol. Palaeoecol., 259, 136-156.

Gradzinski, M., Szulc, J., Motyka, J., Stworzewicz, E. and Tyc, A. (2001) Travertine mound and cave in a village of Laski. Silesian-Cracow Upland. Ann. Soc. Geol. Polon., 71, 115-123.

Guidry, S.A. and Chafetz, H.S. (2003) Anatomy of siliceous hot springs: examples from Yellowstone National Park, Wyoming, USA. Sed. Geol., 1572003, 71-106.

Guo, X. and Chafetz, H.S. (2012) Large tufa mounds, Searles Lake, California. Sedimentology, 59, 1509-1535.

Gutierrez, F., Linares, R., Roque, C., Zarroca, M., Rosell, J., Galve, J.P. and Carbonel, D. (2012a) Investigating gravitational grabens related to lateral spreading and evaporite dissolution subsidence by means of detailed mapping, trenching, and electrical resistivity tomography (Spanish Pyrenees). Lithosphere, 4, 331-353.

Gutiérrez, F., Carbonel, D., Guerrero, J., McCalpin, J.P., Linares, R., Roque, C. and Zarroca, C. (2012b) Late Holocene episodic displacement on fault scarps related to interstratal dissolution of evaporites (Teruel Neogene Graben, NE Spain). J. Struct. Geol., 34, 2-19.

Gutiérrez, F., Valero-Garcés, B., Desir, G., GonzálezSampériz, P., Gutiérrez, M., Linares, R., Zarroca, M., Moreno, A., Guerrero, J., Roqué, C., Arnold, L.J. and Demuro, M. (2013) Late Holocene evolution of playa lakes in the central sector of the Ebro Depression based on geophysical surveys and morphostratigraphic analysis of lacustrine terraces. Geomorphology, 196, 177-197.

Hancock, P.L., Chalmers, R.M., Altunel, E. and Cakir, Z. (1999) Travitonics: using travertines in active fault studies. J. Struct. Geol., 21, 903-916.

Jalut, G., Dedoubat, J.J., Fontugne, M. and Otto, T. (2009) Holocene circum-Mediterranean vegetation changes: climate forcing and human impact. Quatern. Int., 200, 4-18.

Keppel, M.N., Clarke, J.D.A., Halihan, T., Love, A.J. and Werner, A.D. (2011) Mound springs in the arid Lake Eyre South region of South Australia: a new depositional tufa model and its controls. Sed. Geol., 240, 55-70.

Keppel, M.N., Post, V.E.A., Crossey, L.J., Clarke, J.D.A., Love, A.J. and Werner, A.D. (2012) Influences on the carbonate hydrochemistry of mound spring environments, Lake Eyre South region, South Australia. Chem. Geol., 296-297, 50-65. 
King, G. (1994) Late Quaternary paleolakes of Butte Valley, Siskiyou County, California. In: The California Geographer (Eds E. McIntire, B. Takizawa and J. Zorn), vol. XXXIV, pp. 41-57. The California Geographical Society, Chicago, CA.

Linares, R. (1995) La Geología Ambiental de la depresión de Tremp-Isona (Pallars Jussà). Publicaciones de la Universitat Autònoma de Barcelona, Bellaterra, 235 pp.

Linares, R., Menció, A., Rivas, G., Casadellà, L. and Rodríguez, A. (2008) Caracterització hidrogeològia de la massa d'aigua 43. Agència Catalana de l'Aigua, Barcelona. Unpublished report.

Linares, R., Rosell, J., Roqué, C. and Gutiérrez, F. (2010a) Origin and evolution of tufa mounds related to artesian karstic springs in Isona area (Pyrenees, NE Spain). Geodin. Acta, 23, 129-150.

Linares, R., Roqué, C. and Copons, R. (2010b) Mapa geoantròpic num. 290-2-1(Isona). Mapa Geològic de Catalunya E. 1:25.000. Institut Geològic de Catalunya, Barcelona.

Machette, M.N. (1985) Calcic soils of southwestern United States. In: Soil and Quaternary Geology of the Southwestern United States (Ed. D.L. Weide), Geol. Soc. Am. Spec. Pap., 203, 1-21.

Mayewski, P.A., Rohling, E.E., Curt Stager, J., Karlén, W., Maasch, K.A., David Meeker, L., Meyerson, E.A., Gasse, F., van Kreveld, S., Holmgren, K., Lee-Thorp, J., Rosqvist, G., Rack, F., Staubwasser, M., Schneider, R.R. and Steig, E.J. (2004) Holocene climate variability. Quatern. Res., 62, 243-255.

McCalpin, J.P. (2009) Field techniques in Paleoseismology. Terrestrial environments. In: Paleoseismology (Ed. J.P. McCalpin), pp. 29-118. Academic Press, San Diego, CA.

McCalpin, J.P. (2013) Trenching and exposed faces. In: Methods in Geomorphology. Treatise on Geomorphology (Eds A. Switzer and D.M. Kennedy), vol. 14, pp. 138-149. Elsevier, Amsterdam.

Melles, M., Brigham-Grette, J., Minyuk, P.S., Nowaczyk, N.R., Wennrich, V., DeConto, R.M., Anderson, P.M., Andreev, A.A., Coletti, A., Cook, T.L., Haltia-Hovi, E., Kukkonen, M., Lozhkin, A.V., Rosen, P., Tarasov, P., Vogel, H. and Wagner, B. (2012) 2.8 million years of Arctic climate change from Lake El'gygytgyn, NE Russia. Science, 337, 315-320.

Meyers, P.A. (2003) Applications of organic geochemistry to paleolimnological reconstructions: a summary of examples from the Laurentian Great Lakes. Org. Geochem., 34, 261-289.

Morellón, M., Valero-Garcés, B., Moreno, A., GonzálezSampériz, P., Mata, P., Romero, O., Maestro, M. and Navas, A. (2008) Holocene palaeohydrology and climate variability in northeastern Spain: the sedimentary record of Lake Estanya (Pre-Pyrenean range). Quatern. Int., 181, 15-31.

Morellón, M., Valero-Garcés, B., Vegas-Vilarrúbia, T., González-Sampériz, P., Romero, O., Delgado-Huertas, A., Mata, P., Moreno, A., Rico, M. and Corella, J.P. (2009a) Late Glacial and Holocene palaeohydrology in the western Mediterranean region: the Lake Estanya record (NE Spain). Quatern. Sci. Rev., 28, 2582-2599.

Morellón, M., Valero-Garcés, B.L., Anselmetti, F., Ariztegui, D., Schnellmann, M., Moreno, A., Mata, P., Rico, M. and Corella, J.P. (2009b) Late Quaternary deposition and facies model for karstic Lake Estanya (NE Spain). Sedimentology, 56, 1505-1534.

Moreno, A., Valero-Garcés, B.L., Jiménez-Sánchez, M., Domínguez-Cuesta, M.J., Mata, M.P., Navas, A., GonzálezSampériz, P., Stoll, H., Farias, P., Morellón, M., Corella,
J.P. and Rico, M. (2010) The last deglaciation in the Picos de Europa National Park (Cantabrian Mountains, northern Spain). J. Quatern. Sci., 25(7), 1076-1091.

Murray, A.S. and Wintle, A.G. (2003) The single aliquot regenerative dose protocol: potential for improvements in reliability. Radiat. Meas., 37, 377-381.

Obermaier, S.F. (2009) Using liquefaction-induced and other soft-sediment features for paleoseismic analysis. In: Paleosesismology (Ed. J.P. McCalpin), pp. 497-564. Elsevier, Amsterdam.

Pedley, H.M. (1990) Classification and environmental models of cool freshwater tufas. Sed. Geol., 68, 143-154.

Pedley, M. (2009) Tufas and travertines of the Mediterranean region: a testing ground for freshwater carbonate concepts and developments. Sedimentology, 56, 221-246.

Pellicer, X.M., Linares, R., Gutiérrez, F., Comas, X., Roqué, C., Carbonel, D., Zarroca, M. and Rodríguez, J.A.P. (2014) Morpho-stratigraphic characterization of a tufa mound complex in the Spanish Pyrenees using ground penetrating radar and trenching, implications for studies in Mars. Earth Planet. Sci. Lett., 388, 197-210.

Pentecost, A. (2005) Travertine. Springer, Berlin, 445 pp.

Pèrez-Obiol, R. and Julià, R. (1994) Climatic Change on the Iberian Peninsula Recorded in a 30,000-Yr Pollen Record from Lake Banyoles. Quatern. Res., 41, 91-98.

Pérez-Sanz, A., González-Sampériz, P., Moreno, A., ValeroGarcés, B., Gil-Romera, G., Rieradevall, M., Tarrats, P., Lasheras-Álvarez, L., Morellón, M., Belmonte, A., Sancho, C., Sevilla-Callejo, M. and Navas, A. (2013) Holocene climate variability, vegetation dynamics and fire regime in the central Pyrenees: the Basa de la Mora sequence (NE Spain). Quatern. Sci. Rev., 73, 149-169.

Pola, M., Gandin, A., Tuccimei, P., Soligo, M., Deianas, R., Fabbri, P. and Zampieri, D. (2014) A multidisciplinary approach to understanding carbonate deposition under tectonically controlled hydrothermal circulation: a case study from a recent travertine mound in the Euganean hydrothermal system, northern Italy. Sedimentology, 61, 172-199.

Priewisch, A., Crossey, L.J., Karlstrom, K.E., Polyak, V.J., Asmerom, Y., Nereson, A. and Ricketts, J.W. (2014) Useries geochronology of large-volume Quaternary travertine deposits of the southeastern Colorado Plateau: evaluating episodicity and tectonic and paleohydrologic controls. Geosphere, 10-2, 401-423.

Reheis, M.C. and Miller, D.M. (2010) Environments of nearshore lacustrine deposition in the Pleistocene Lake Manix basin, south-central California. In: Overboard in the Mojave: 20 Million Years of Lakes and Wetlands (Eds R.E. Reynolds and D.M. Miller), Abst. Proc. Zzyzx, CA, pp. 24-37.

Reimer, P.J., Bard, E., Bayliss, A., Beck, J.W., Blackwell, P.G., Ramsey, C.B., Buck, C.E., Cheng, H., Edwards, R.L., Friedrich, M., Grootes, P.M., Guilderson, T.P., Haflidason, H., Hajdas, I., Hatte, C., Heaton, T.J., Hoffmann, D.L., Hogg, A.G., Hughen, K.A., Kaiser, K.F., Kromer, B., Manning, S.W., Niu, M., Reimer, R.W., Richards, D.A., Scott, E.M., Southon, J.R., Staff, R.A., Turney, C.S.M. and van der Plicht, J. (2013) Intcal13 and Marine13 radiocarbon age calibration curves, 050,000 years cal BP. Radiocarbon, 55, 1869-1887.

Renaut, R.W., Bernhart, O., Jones, B., Tiercelins, J.J., Corinne, T., Ego, J.K. and Konhauser, K.O. (2013) Impact of lake-level changes on the formation of thermogene travertine in continental rifts: evidence from Lake Bogoria, Kenya Rift Valley. Sedimentology, 60, 428-468. 
Revelles, J., Cho, S., Iriarte, E., Burjachs, F., van Geel, B., Palomo, A., Piqué, R., Peña-Chocarro, L. and Terradas, X. (2015) Mid-Holocene vegetation history and Neolithic land-use in the Lake Banyoles area (Girona, Spain). Palaeogeogr. Palaeoclimatol. Palaeoecol., 435, 70-85.

Roqué, C., Linares, R., Zarroca, M., Rosell, J., Mir, X. and Gutiérrez, F. (2013) Chronology and paleoenvironmental interpretation of talus flatiron sequences in a sub-humid mountainous area: Tremp Depression, Spanish Pyrenees. Earth Surf. Proc. Land., 38, 1513-1522.

Rosell, J. (1996) Mapa Geológico de España a escala 1:50.000, Hoja n? 290. (Isona), ITGE, Madrid, 290 pp.

Rosell, J., Linares, R. and Llompart, C. (2001) El Garumniense Prepirenaico. Rev. Soc. Geol. Esp., 14, 47-56.

Rosen, M.R., Arehart, G.B. and Lico, M.S. (2004) Exceptionally fast growth rate of $<100$-yr-old tufa, Big Soda Lake, Nevada: implications for using tufa as a paleoclimate proxy. Geology, 32, 409-412.

Rull, V., González-Sampériz, P., Corella, J.P., Morellón, M. and Giralt, S. (2011) Vegetation changes in the southern Pyrenean flank during the last millennium in relation to climate and human activities: the Montcortès lacustrine record. J. Paleolimnol., 46, 387-404.

Scheuer, G. and Schweitzer, F. (1985) Types and forms of travertine cones. Földtani Közlöny, 115, 385-398.

Scussolini, P., Vegas-Vilarrúbia, T., Rull, V., Corella, J.P., Valero-Garcés, B. and Gomà, J. (2011) Middle and late Holocene climate change and human impact inferred from diatoms, algae and aquatic macrophyte pollen in sediments from Lake Montcortès (NE Iberian Peninsula). $J$. Paleolimnol., 46, 369-385.
Teixell, A. (2004) La estructura tectónica alpina de la Cordillera Pirenaica. In: Geología de España (Ed. J.A. Vera), pp. 320-328. Sociedad Geologica de España IGME, Madrid, Spain.

Toker, E., Kayseri-Özer, M.S., Özkul, M. and Kele, S. (2015) Depositional system and palaeoclimatic interpretations of Middle to Late Pleistocene travertines: Kocabaş, Denizli, south-west Turkey. Sedimentology, 62, 1360-1383.

Valero Garcés, B.L., Moreno, A., Navas, A., Mata, P., Machín, J., Delgado Huertas, A., González Sampériz, P., Schwalb, A., Morellón, M., Cheng, H. and Edwards, R.L. (2008) The Taravilla lake and tufa deposits (Central Iberian Range, Spain) as palaeohydrological and palaeoclimatic indicators. Palaeogeogr. Palaeoclimatol. Palaeoecol., 259, 136-156.

Valero-Garcés, B., Morellón, M., Moreno, A., Corella, J.P., Martín-Puertas, C., Barreiro, F., Pérez, A., Giralt, S. and Mata-Campo, M.P. (2014) Lacustrine carbonates of Iberian Karst Lakes: sources, processes and depositional environments. Sed. Geol., 299, 1-29.

Vegas-Vilarrúbia, T., González-Sampériz, P., Morellónc, M., Gil-Romera, G., Pérez-Sanz, A. and Valero-Garcés, B. (2013) Diatom and vegetation responses to Late Glacial and Early Holocene climate changes at Lake Estanya (Southern Pyrenees, NE Spain). Palaeogeogr. Palaeoclimatol. Palaeoecol., 392, 335-349.

Manuscript received 29 October 2015; revision accepted 8 April 2016 